\title{
Subjective Well-being Across the Lifespan in Europe and Central Asia
}

Bauer, Jan Michael; Levin, Victoria; Munoz Boudet, Ana Maria; Nie, Peng; Sousa-Poza, Alfonso

\author{
Document Version \\ Accepted author manuscript \\ Published in: \\ Journal of Population Ageing \\ DOI: \\ 10.1007/s12062-016-9148-0 \\ Publication date: \\ 2017 \\ License \\ Unspecified
}

Citation for published version (APA):

Bauer, J. M., Levin, V., Munoz Boudet, A. M., Nie, P., \& Sousa-Poza, A. (2017). Subjective Well-being Across the Lifespan in Europe and Central Asia. Journal of Population Ageing, 10(2), 125-158.

https://doi.org/10.1007/s12062-016-9148-0

Link to publication in CBS Research Portal

\section{General rights}

Copyright and moral rights for the publications made accessible in the public portal are retained by the authors and/or other copyright owners and it is a condition of accessing publications that users recognise and abide by the legal requirements associated with these rights.

\section{Take down policy}

If you believe that this document breaches copyright please contact us (research.lib@cbs.dk) providing details, and we will remove access to the work immediately and investigate your claim.

Download date: 26. Apr. 2023

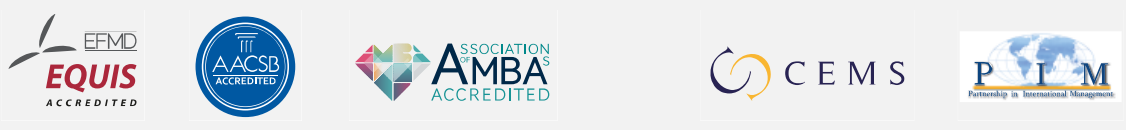




\title{
Subjective Well-being Across the Lifespan in Europe and Central Asia
}

\section{Jan Michael Bauer, Victoria Levin, Anna Maria Munoz Boudet, Peng Nie, and Alfonso Sousa-Poza}

Journal article (Post print version)

\begin{abstract}
CITE: Subjective Well-being Across the Lifespan in Europe and Central Asia. / Bauer, Jan Michael; Levin, Victoria; Munoz Boudet, Ana Maria; Nie, Peng; Sousa-Poza, Alfonso. In: Journal of Population Ageing, 11.05.2016.
\end{abstract}

The final publication is available at Springer via 10.1007/s12062-016-9148-0

Uploaded to Research@CBS: December २016 


\title{
Subjective well-being across the lifespan in Europe and Central Asia
}

Jan Michael Bauer ${ }^{1} \&$ Victoria Levin ${ }^{2}$ \&Ana Maria Munoz Boudet ${ }^{2} \&$ Peng Nie $^{3}$ \&Alfonso Sousa-Poza ${ }^{3}$

\begin{abstract}
Using data from the Integrated Values Survey (IVS), the Life in Transition Survey (LiTS), and the Russia Longitudinal Monitoring Survey (RLMS), we analyse the relation between age and subjective well-being in the World Bank's Europe and Central Asia (ECA) region and compare it to that in Western Europe. Although our results generally confirm previous studies' findings of a U-shaped relation between subjective well-being and age for most of the lifecycle, we also find that well-being in ECA declines again after the 70s, giving rise to an Sshape relation across the entire lifespan. When controlling for socio-demographic characteristics, this pattern generally remains robust for most of our cross-sectional and panel analyses. Hence, despite significant heterogeneity in the pattern of well-being across the lifespan within the ECA region, we do not observe high levels of cross-country or crosscohort variation.
\end{abstract}

JEL classification Codes: C23; D1; I31; J1

Keywords: Age, subjective well-being, Eastern Europe, Central Asia, life satisfaction

${ }^{1}$ Department of Intercultural Communication and Management, Copenhagen Business School,

Frederiksberg, Denmark

${ }^{2}$ World Bank, Washington, DC, USA

${ }^{3}$ Institute for Health Care \& Public Management, University of Hohenheim, 70599 Stuttgart,

Germany 


\section{Subjective well-being across the lifespan in Europe and Central Asia}

\section{Introduction}

A large body of literature on the relation between age and subjective well-being has emerged in the past years. This field of research has been strongly influenced by the seminal paper of Blanchflower and Oswald (2008), which documents a U-shaped relation for well-being over the lifespan (with a minimum at around middle age) in most of the approximately 74 countries included in the analysis. Yet some controversy still remains over this U-shaped relation with as many papers refuting it (e.g., Frijters and Beatton, 2012; Kassenboehmer and Haisken-DeNew, 2012; Baetschmann, 2014) as supporting it (e.g., Clark, 2007; Van Landegham, 2008, 2012; Blanchflower and Oswald, 2011; Weiss et al., 2012). ${ }^{1}$ Fischer (2009), using an OECD sub-sample of the World Values Survey (WVS), concludes that an Sshape with a cubic functional form in which well-being decreases in old age is a more accurate description of the well-being pattern across the lifecycle. Much of the ensuing literature also focuses almost exclusively on large-scale panel data in high-income countries; for example, the British Household Panel, the German Socioeconomic Panel, and the Household Income Labour Dynamics in Australia.

Deaton (2008) expands this focus to include developing countries, arguing that the wellbeing/age relation may be mediated by culture. In his analysis of cross-sectional data from the 2006 Gallup World Poll, he reveals that the age profiles of self-reported life satisfaction differ significantly from country to country. Although this analysis does not control for covariates, his use of Gallup World Poll data facilitates cross-country comparisons and encompasses nationally representative samples of individuals from over 130 countries. Based on his

\footnotetext{
${ }^{1}$ See Lopez Ulloa et al. (2013) for a recent literature review.
} 
observation of general life satisfaction among individuals from different age groups, Deaton (2008) argues that the U-shaped relation is present only in rich English-speaking countries. Similar results are obtained by a subsequent analysis of the Gallup World Poll; the age pattern of multiple well-being measures shows substantial differences between high-income Englishspeaking countries; countries in Sub-Saharan Africa; countries in Latin America and the Caribbean; and countries from the former Soviet Union and Eastern Europe. The U-shape is only present in the high-income English-speaking group, while well-being seems to decline with age in the last group (Steptoe et al., 2015).

The aim of our study is to analyse the relation between age and subjective well-being in a region that to date has received relatively scarce attention in the literature: the World Bank's Europe and Central Asia (ECA) region. ${ }^{2}$ This region warrants investigation not only because of the diverse cultures it encompasses but also because of the significant institutional and economic transformations many of its countries have undergone in the past few decades. Whereas the region's cultural diversity permits us to test the universality of the U-shape hypothesis across different country contexts, the transformations experienced by most of these countries in the 1990s enable us to capture variations across cohorts whose economic and social environments differed radically at different points in the lifecycle. Thus, our underlying hypothesis is that, if a similar pattern of subjective well-being across the lifespan can be observed in this region (marked by economic and political turmoil) and despite using several different data sets collected at different points in time and by implementing various methodological approaches (including panel analyses), then these patterns are most likely not an artefact of specific national or cultural peculiarities. Our results do indeed support the

\footnotetext{
${ }^{2}$ These countries are the Western Balkans (Albania, Bosnia and Herzegovina, Kosovo, FYR Macedonia, Montenegro, Serbia ), the Eastern Partnership and Russian Federation (Armenia, Belarus, Georgia, Moldova, Ukraine, Russian Federation), Central Europe (Bulgaria, Croatia, Croatia, Hungary, Poland, Romania, Slovak Republic, Slovenia), Central Asia and Turkey (Azerbaijan, Kazakhstan, Kyrgyz Republic, Tajikistan, Turkey, Turkmenistan , Uzbekistan ), and the Baltics (Estonia, Latvia, Lithuania)
} 
presence of a U-shaped relation for most of the lifecycle and in most countries. We also find evidence of another turning point later in life (during the 70s or 80s), after which well-being in ECA begins to decline again, giving rise to an S-shape across the entire lifespan. However, when we estimate the unconditional lifecycle pattern, the results differ between the ECA and the Western European comparison group. While excluding all covariates barely alters the pattern for Western Europe, we cannot observe increasing well-being in old age among the ECA countries.

The remainder of the paper proceeds as follows: Section 2 briefly discusses some past research for the ECA region. Section 3 describes the data sets and different methodological approaches. Section 4 reports our empirical results and section 5 concludes.

\section{Previous research in the ECA region}

With few exceptions (Blanchflower and Oswald, 2008; Deaton, 2008; Realo and Dobewall, 2011; Steptoe et al., 2015), studies of subjective well-being in the ECA region have not focused on an in-depth analysis of the interdependence between this variable and age. Rather, well-being regressions in most studies use age only as a potential covariate that is controlled when examining the association between well-being and such aspects as income (Frijters et al., 2006), the transition process (Hayo, 2007), and/or the correlations among different subjective welfare measures (Cojocaru and Diagne 2015). In contrast to Deaton (2008) and Steptoe et al. (2015), these ECA studies consistently find a U-shaped pattern across the region, although they differ in both the way that well-being is defined ${ }^{3}$ and the precise shape and location of the minimum. Country-specific evidence from the WVS also

\footnotetext{
${ }^{3}$ Minima vary from 37 (Hayo and Seifert, 2003) to 44 (Hayo, 2007) to 46.5 (48.2) for men (women) (Blanchflower and Oswald, 2008).
} 
supports the U-shape for most countries in the ECA region (Namazie and Sanfey, 2001; Blanchflower and Oswald, 2008). ${ }^{4}$

For the Russian Federation, cross-sectional analyses using the Russia Longitudinal Monitoring Survey (RLMS) also find life satisfaction to be U-shaped in age, with a minimum in well-being between 45 and 55 (Graham and Pettianto, 2002; Ravallion and Lokshin, 2002; Graham et al., 2004). However, by exploiting the panel aspect of the RLMS (data from 1994 to 2010) and accounting for individual fixed effects, Massin and Kopp (2014) estimate a nonlinear specification of age that places the lowest levels of well-being at age 30-39. They also find that the level of well-being for the oldest age group (70 and above) is statistically similar to that for people aged 20 years and younger.

Our contribution to the research is twofold: first, by performing a systematic assessment of the relation between subjective well-being and age across the entire ECA region, we greatly expand on the findings from more geographically limited studies. We accomplish this expansion by using three large-scale surveys: the Integrated Values Survey (IVS), the Life in Transition Survey (LiTS), and the Russia Longitudinal Monitoring Survey (RLMS). Second, our analysis is to our knowledge the first in-depth study of the relation between age and wellbeing using a large-scale panel data set from a non-Western country (i.e. the Russian Federation).

\footnotetext{
${ }^{4}$ Specifically, the U-shaped relation is found for Azerbaijan, Belarus, Bosnia and Herzegovina, Bulgaria, Croatia, Czech Republic, Estonia, Kyrgyz Republic, Latvia, Lithuania, FYR Macedonia, Poland, Romania, Serbia, Slovakia, Turkey and Russian Federation.
} 


\section{Data and methods}

\subsection{Data}

The empirical results of this study are based on three different data sets: the Integrated Values Survey (IVS), the Life in Transition Survey (LiTS), and the Russia Longitudinal Monitoring Survey (RLMS). The IVS data set merges the four-wave European Values Study (EVS, 1981-2008) with the five-wave World Values Survey (WVS, 1981-2009). ${ }^{5}$ The EVS, begun in 1981 and repeated every 9 years, is a large-scale, cross-national, longitudinal survey that provides insights into the ideas, beliefs, preferences, attitudes, values, and opinions of citizens all over Europe. Nationally representative of the population 18 years and older, in its first wave, it sampled 1,000 individuals per country, and then for its fourth wave, administered in 2008, expanded to a multistage random sampling of 1,500 interviews per country. This last wave covers 25 of the 30 ECA countries: Albania, Armenia, Azerbaijan, Belarus, Bosnia and Herzegovina, Bulgaria, Croatia, Czech Republic, Estonia, Georgia, Hungary, Kosovo Republic, Latvia, Lithuania, FYR Macedonia, Moldova, Montenegro, Poland, Romania, Russian Federation, Serbia, Slovak Republic, Slovenia, Turkey and Ukraine.

The WVS, administered in six waves from 1981 to 2014, is a global research project that investigates the changes in individual's beliefs and values and how these changes influence social and political development throughout the world. It samples a minimum of 1,000 interviewees aged 18-85 in 23 ECA countries: Albania, Armenia, Azerbaijan, Belarus, Bosnia and Herzegovina, Bulgaria, Croatia, Czech Republic, Estonia, Georgia, Hungary, Kyrgyz Republic, Latvia, FYR Macedonia, Moldova, Poland, Romania, Russian Federation, Serbia, Slovak Republic, Slovenia, Turkey and Ukraine. The resulting compilation, the IVS, assesses individual life satisfaction with the following question: All things considered, how

\footnotetext{
${ }^{5}$ The surveyed years for the four-wave EVS are: 1981, 1990, 1999/2000 and 2008. For the five waves of WVS, the surveyed years are: 1981-1984, 1990-1994, 1995-1998, 1999-2004 and 2005-2009.
} 
satisfied are you with your life as a whole these days? Responses are measured on a scale from 1 (dissatisfied) to 10 (satisfied).

The LiTS, a joint project of the European Bank for Reconstruction and Development (EBRD) and the World Bank, examines the impact of economic and political transition on individuals' lives (and well-being), as well as their future hopes for Central Eastern Europe, the Baltic States, and South Eastern Europe. Its two waves, conducted in 2006 and 2010, covered approximately 58,000 individuals in 29 ECA countries (all except Turkmenistan). In the LiTS, individual life satisfaction is measured as follows: To what extent do you agree with the following statements? All things considered, I am satisfied with my life now. Responses on this question are assessed on a scale from 1 (strongly disagree) to 5 (strongly agree).

The RLMS, a nationally representative survey of households in the Russian Federation, is designed to evaluate the impact of Russian reforms on welfare and health. Although the survey has collected data on about 10,000 individuals aged 14 and above 21 times since 1992, our analysis is based on 16 waves during the 1995-2013 period. This restriction was necessary, as some variables of interest are not covered in the first five waves. The RLMS evaluates individual life satisfaction as follows: To what extent are you satisfied with your life in general at the present time? Responses are assessed on a 5-point scale from 1 (not at all satisfied) to 5 (fully satisfied). Summary statistics for subjective well-being and respondent socio-demographics from all the above data sources are given in Table A1 of Appendix 1.

The use of three different datasets has several advantages. First, the IVS and LiTS cover most ECA countries (IVS encompasses 26 of 30 ECA countries and the LiTS covers 29). As Easterlin (2016) has emphasized, the EVS is a prototype of the WVS and therefore can be integrated with the WVS to increase both country and time coverage. Although the IVS covers a longer timeframe, which enables us to identify the life-cycle patterns over a longer period (1981-2009). However, these data are not collected at regular intervals. The LiTS covers virtually all countries in the ECA and follows them consistently over the next period, 
but it only has two waves (2006 and 2010). Although the RLMS only covers one (albeit important) ECA country (the Russian Federation), it includes a comprehensive set of variables and contains a long panel (from 1995 to 2013), which allows us to account for unobserved individual heterogeneity, not possible with either IVS or LiTS. Finally, using several sources with different measures serves the objective of determining the generalizability of our results.

\subsection{Estimation approaches}

\subsubsection{Ordinary least squares (OLS): IVS/LiTS}

For the IVS data, we adopt the standard regression approach applied in the majority of studies on subjective well-being (e.g. Blanchflower and Oswald, 2008). Because well-being is measured on an ordered 5-point or 10-point scale, a latent variable analysis might seem the most appropriate method. However, because the bias introduced by a standard ordinary least squares estimation (OLS) is fairly small (Ferrer-i-Carbonell and Frijters, 2004), we rely mostly on OLS. In general, the model is as follows:

$$
L S_{i t}=\beta_{0}+\beta_{1} A G E_{i t}+\beta_{2} X_{i t}+\beta_{3} C+\beta_{4} Y+\varepsilon_{i t},
$$

where $L S_{i t}$ denotes the life satisfaction of individual $i$ at the year of $t . A G E_{i t}$ is included either as a linear or multinomial function of age (i.e. quadratic and cubic terms) or as a set of 5-year age group indicators. We adopt the 5-year clustering for two reasons: (i) to balance the tradeoff between cell size and within-group heterogeneity in well-being and (ii) to facilitate the distinction between age groups, cohort effects, and time. ${ }^{6}$ However, clear identification of all three effects is not possible in an additive linear regression model, as individual age is equal to the difference between the survey year and the birth year. This specification, adopted by

\footnotetext{
${ }^{6} \mathrm{We}$ assume that the well-being of a 50-year-old does not differ systematically from that of a 51-year-old and that a certain category size is needed to capture possible differences in well-being with age. In addition, smaller age groups would result in small cell sizes, especially at the extremes of the age distribution.
} 
Blanchflower and Oswald (2008), achieves identification by clustering the cohort effect as birth decades to allow for some variation between age, period (survey year), and cohort effects (birth year). ${ }^{7}$ This approach does not completely solve the age-period-cohort conundrum (Glenn, 2009). However, the suggested solution by Glenn (2009) and Hellevik (2015) of omitting the period effect from the regression does not seem viable in the context of the ECA countries, as those countries underwent dramatic social and cultural changes over the survey period. $X_{i t}$ represents the characteristics of individual $i$ in year $t$ (see Appendix 2 for a detailed description of the covariates included for each data source). Adding health extends Blanchflower and Oswald's (2008) model and is likely to reduce the bias in the age variable stemming from otherwise omitted deteriorating health in older age. However, as objective health measures are unavailable, we have to rely on a self-rated health indicator. Some researchers oppose subjective health measures as a covariate in well-being regressions, as such self-perceptions are closely linked to the dependent variable. As health can be a crucial determinant of well-being, particularly for the oldest-old (Gwozdz and Sousa-Poza, 2010), we include this measure in our preferred specifications. However, as a robustness test, we also estimate our model without it, with results available upon request. $C$ designates country indicators, $Y$ denotes year dummies, and $\varepsilon_{i t}$ denotes the individual error term. Heteroskedasticity-adjusted standard errors are estimated for coefficients in all specifications.

\footnotetext{
${ }^{7}$ Generally, cohort effects intend to capture the common experiences and perceptions of the world and own wellbeing that can arise from having grown up at the same time. An estimation based on only one cross-section cannot disentangle the cohort effect from the age effect. When more than one cross-section is available, however, a distinction is possible. Including birth-year dummies (see Blanchflower and Oswald, 2008) has been criticized on the grounds that any distinction may remain spurious, and collinearity may be an important issue (Glenn, 2009; Hellevik, 2015).
} 


\subsubsection{Synthetic panel estimation: LiTS}

Following Deaton (1985) and Russell and Fraas (2005), we construct a synthetic (or pseudo) panel for the LiTS data that follows cohorts $^{8}$ of individuals over the 2006-2010 inter-wave period and uses their cohort-specific means for inference. To ensure equal sample means for each cohort, they must be created based on time-invariant characteristics, which in our case are birth-year decades, gender, and country. Because the estimation requires a sufficiently large cell size, we exclude the earliest and latest birth-year decade and drop all countries not covered by both LiTS waves. ${ }^{9}$

For this analysis, we create 336 cohorts based on 28 countries, 6 birth decades, and 2 sexes. For each cohort-year observation, we estimate the mean of the covariates, including age, marital status, employment, education, self-reported health, and household expenditures. By assuming the existence of a fixed group $\bar{\mu}_{g}$ that remains constant over time, we can apply a fixed-group effects estimator; a feasible step (despite the data limitation of two periods within a relatively short timespan of four years) if the sample size in each cell is relatively large and the correlation between the covariates and the unobserved fixed effect is small (Verbeek and Nijman, 1993). To address any heteroskedasticity produced by unequal cell sizes, we also weight each cell by its sample size (Russell and Fraas, 2005). ${ }^{10}$ The model used is as follows:

$$
\overline{L S}_{g t}=\beta_{1} \overline{A G E}_{g t}+\beta_{2} \bar{X}_{g t}+\bar{\mu}_{g}+\varepsilon_{g t}, g=1, \cdots, 336 ; t=1,2 \text {, }
$$

\footnotetext{
${ }^{8}$ Cohorts in the context of synthetic panels not only refer to the year of birth and should not be confused with the cohort variables used in other parts in this paper,

${ }^{9}$ The gender differences in life expectancy are notably substantial in some ECA countries. In the Russian Federation, for instance, women live on average more than 10 years longer than men, which must be taken into account when looking at the joint distribution. However, the gender split analysis of the RLMS data shows no major differences in well-being/age patterns between the sexes.

${ }^{10}$ This weighted method has some limitations related to data availability. On the one hand, if the sample size within each group does not exceed thousands of observations, the measurement error can be large (Devereux, 2007). On the other, the groups must be sufficiently homogeneous for the assumption of fixed group effects to remain justifiable, meaning that clustering groups over different countries would introduce another bias. We thus treat the results of this approach with caution but compare them with our pooled cross-sectional analysis estimates to check robustness.
} 
where $\overline{L S}_{g t}$ and $\bar{X}_{g t}$ represent the average life satisfaction and average time-variant characteristics, respectively, of individuals in group g at time $t$. To achieve identification, we do not include a time dummy into the regression (Glenn, 2009; Hellevik, 2015), which appears reasonable given that we only have two periods in the LiTS. $\varepsilon_{g t}$ is the disturbance error term (see Russell and Fraas, 2005).

\subsubsection{Fixed-effects panel estimation: RLMS}

For the RLMS, we additionally explore the U-shape in the age/well-being nexus using a fixed effects that is expressed as follows:

$$
L S_{i t}=\beta_{0}+\beta_{1} A G E_{i t}+\beta_{2} X_{i t}+\mu_{i}+\varepsilon_{i t}
$$

where $L S_{i t}$ and $A G E_{i t}$ indicates the life satisfaction and age, respectively, of individual $i$ at time $t$. As the within transformation of the fixed-effects model leads to a collinearity with the time dummies, we follow the approach previously applied by Clark (2007) and Gwozdz and Sousa-Poza (2010) and include age in its nonparametric form. ${ }^{11} X_{i t}$ is a vector of individual $i$ 's time-variant characteristics, $\mu_{i}$ represents unobservable time-invariant individual effects, and $\varepsilon_{i t}$ is the disturbance error term.

\subsubsection{Inclusion of controls}

Studies analysing how life satisfaction evolves across the lifespan differ in their treatment of control variables. Ultimately, whether or not to include covariates depends on the underlying research objective. If our interest is in the general trend of life satisfaction across the lifespan, then control variables should be omitted. If, however, our interest is in assessing the "pure"

\footnotetext{
${ }^{11}$ If panel data are available (i.e. the same individual is observed over time), cohort effects can be perceived as a time-invariant characteristic that can be eliminated by accounting for individual fixed effects. However, perfect identification is still difficult when time (period effect) and age are included. For a critical discussion of the approach and identification, see Baetschmann (2014), De Ree and Alessie (2011), and Ferrer-i-Carbonell and Frijters (2004).
} 
age effect, then we should control for as many factors as possible that could affect life satisfaction besides age. Easterlin (2006, p. 465) prefers the former specification, arguing that "if one wants to know whether a person is likely to be happier in his or her golden years than when forming families, one would not want to set aside the fact that older people are likely to have lower income, and be less healthy, and are more likely to be living alone" (for further discussion see also Glenn, 2009). However, when analysing the U-shape relationship, we are particularly interested in the pure age affect, i.e. in trying to identify a so-called "mid-life crisis," which is unrelated to possible financial difficulties, health problems, household structure, and the like. To address both objectives, we show our main results with and without controls for Western Europe and ECA countries and discuss any significant changes that occur between the two specifications.

\section{Results}

Although Blanchflower and Oswald (2008) provide comprehensive evidence of a robust Ushaped pattern for most subsamples of the IVS data set, Fischer (2009) proposes an S-shaped relation with decreasing well-being in higher age as a better fit. We thus test different age specifications to determine the most adequate model for the ECA region. First, we compare the age coefficients, in different forms, between a set of ECA countries ${ }^{12}$ and Western European countries ${ }^{13}$. Table 1 presents the results of a comparison between the two IVS subsamples from 1981 until 2009 for individuals aged 18 to 108, while Figure 1 illustrates the corresponding average marginal effects for regressions (1) to (6). In line with the U-shape hypothesis, the squared terms are significant for both samples. The average individual in an

\footnotetext{
${ }^{12}$ Albania, Armenia, Azerbaijan, Belarus, Bosnia and Herzegovina, Bulgaria, Croatia, Czech Republic, Estonia, FYR Macedonia, Georgia, Hungary, Kosovo Republic, Kyrgyz Republic, Latvia, Lithuania, Moldova, Montenegro, Poland, Romania, Russian Federation, Serbia, Slovak Republic, Slovenia, Turkey, Ukraine.

${ }^{13}$ France, United Kingdom, Austria, Belgium, Luxembourg, the Netherlands, Switzerland, West Germany, and East Germany.
} 
ECA country reaches the nadir of well-being at age 48.8 (column 1), more than 10 years later than the average Western European, whose well-being starts increasing after age 35.4 (column 2).

Estimations (3) and (4) in Table 1 add a cubic term for age, which allows for a more flexible relation with well-being. The coefficient on the cubic term is significant for both ECA and Western Europe, implying an S-shape with decreasing well-being in old age. For ECA countries, controlling for other covariates, well-being decreases with age to a local minimum at 42.9 and recovers to the average value reported by youth by the early 80 s (see Figure 1, middle-left panel). Thereafter, well-being declines for the oldest old, even though the small sample size leads to larger standard errors, which makes precise interpretation difficult. Although the coefficient on the cubic term of age for Western Europe is also significant and negative, the maximum occurs much later (93.8 versus 82.4 in the ECA) and the level of well-being reached at the maximum is higher than that observed for youth (Figure 1 , middle-right panel).

The final two columns in Table 1 impose no specific functional form on age but rather use age group clusters. Compared to the omitted reference age group of 18-22, well-being in ECA countries is lower for all other age groups, a pattern evident in column (5). Figure 1 demonstrates that well-being in ECA decreases until the late 40s and then recovers slightly over the next 40 years (bottom-left panel). It does not, however, reach levels comparable to those experienced by youth until the early 80 s and never significantly exceeds those levels. The largest negative coefficients occur in the 43-47 age group, echoing the results from regression (3).

For the Western European comparison group (column 6), the age dummies show only a slight decrease in well-being from the levels attained in youth, with a minimum for those in their 30s. Thereafter, well-being seems to remain somewhat constant, with the coefficients losing significance until the 60 s, which implies that well-being resembles that of the 18-22 
reference age group. The point estimates then become positive and significant in the 70 s and increase up to the second-oldest age group (83-87).

Figure 1 clearly shows that well-being in the ECA countries tends to be generally lower and exhibits a slightly different lifecycle pattern from the Western European comparison group. Whereas in Western Europe the highest level of well-being occurs among the oldest old across all specifications, in ECA countries higher levels among the old appear only in the squared specification. Subsequently, therefore, we employ a more flexible specification, which reveals a decrease in well-being at a very high age. Comparing (3) and (5) in Figure 1, for example, shows that the dummy mimics the cubic S-shape slightly better than the Ushape, which is in line with previous studies by Deaton (2008), Fischer (2009), and Gwozdz and Sousa-Poza (2010).

Without controlling for observable individual characteristics, our results (Table A2 in the Appendix 1) still confirm a significant squared term for both samples, although the minima occurs somewhat later in life with 86.7 for the ECA and 50.1 for Western Europe. Similarly, for the S-shape hypothesis we find significant coefficients for the cubic specification for both samples, but can only confirm the existence of turning points for Western Europe. For the ECA countries, we obtain a steadily decreasing function. When using different age groups, once again, relative to the reference age group of 18-22, we find well-being in ECA countries to be lower for all other age clusters. However, with regard to Western European countries, the age dummies reveal a modest decline in well-being, with a minimum at ages $48-52$. The corresponding average marginal effects for the regressions in Table A2 are shown in Figure A1 of Appendix 1. 
Table 1 OLS estimates for ECA countries and Western Europe: IVS data (1981-2009)

\begin{tabular}{|c|c|c|c|c|c|c|}
\hline & $\begin{array}{c}\text { ECA } \\
(1)\end{array}$ & $\begin{array}{l}\text { Western Europe } \\
\text { (2) }\end{array}$ & $\begin{array}{c}\text { ECA } \\
(3)\end{array}$ & $\begin{array}{c}\text { Western Europe } \\
\text { (4) }\end{array}$ & $\begin{array}{c}\text { ECA } \\
(5)\end{array}$ & $\begin{array}{c}\text { Western Europe } \\
\text { (6) }\end{array}$ \\
\hline Age & $\begin{array}{l}-0.0478^{* * * *} \\
(0.005)\end{array}$ & 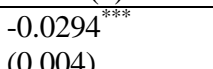 & $\begin{array}{l}-0.1367^{* * * *} \\
(0.022)\end{array}$ & $-0.1140^{* * * *}$ & & \\
\hline Age squared & $\begin{array}{l}0.0005^{* * * *} \\
(0.000)\end{array}$ & $\begin{array}{l}0.0004^{* * * *} \\
(0.000)\end{array}$ & $\begin{array}{l}0.0024^{* * * *} \\
(0.000)\end{array}$ & $\begin{array}{l}0.0022^{* * * *} \\
(0.000)\end{array}$ & & \\
\hline Age cubic & & & $\begin{array}{l}-0.00001^{* * * *} \\
(0.000)\end{array}$ & $\begin{array}{l}-0.00001^{* * * *} \\
(0.000)\end{array}$ & & \\
\hline Age $23-27$ & & & & & $\begin{array}{l}-0.2740^{* * * *} \\
(0.074)\end{array}$ & $\begin{array}{l}-0.1158^{*} \\
(0.059)\end{array}$ \\
\hline Age $28-32$ & & & & & $\begin{array}{l}-0.4131^{* * * *} \\
(0.066)\end{array}$ & $\begin{array}{l}-0.1848^{* *} \\
(0.059)\end{array}$ \\
\hline Age $33-37$ & & & & & $\begin{array}{l}-0.4818^{* * * *} \\
(0.068)\end{array}$ & $\begin{array}{l}-0.2055^{*} \\
(0.101)\end{array}$ \\
\hline Age $38-42$ & & & & & $\begin{array}{l}-0.5272^{* * * *} \\
(0.094)\end{array}$ & $\begin{array}{l}-0.2374 \\
(0.128)\end{array}$ \\
\hline Age $43-47$ & & & & & $\begin{array}{l}-0.5741^{* * * *} \\
(0.085)\end{array}$ & $\begin{array}{l}-0.2021 \\
(0.126)\end{array}$ \\
\hline Age $48-52$ & & & & & $\begin{array}{l}-0.5096^{* * * *} \\
(0.081)\end{array}$ & $\begin{array}{l}-0.1749 \\
(0.109)\end{array}$ \\
\hline Age 53-57 & & & & & $\begin{array}{l}-0.4985^{* * *} \\
(0.072)\end{array}$ & $\begin{array}{l}-0.0666 \\
(0.120)\end{array}$ \\
\hline Age $58-62$ & & & & & $\begin{array}{l}-0.4050^{* * * *} \\
(0.070)\end{array}$ & $\begin{array}{l}0.1273 \\
(0.152)\end{array}$ \\
\hline Age $63-67$ & & & & & $\begin{array}{l}-0.3085^{* * *} \\
(0.074)\end{array}$ & $\begin{array}{l}0.3423^{*} \\
(0.163)\end{array}$ \\
\hline Age $68-72$ & & & & & $\begin{array}{l}-0.2791^{* * * *} \\
(0.086)\end{array}$ & $\begin{array}{l}0.3759^{* * *} \\
(0.155)\end{array}$ \\
\hline Age $73-77$ & & & & & $\begin{array}{l}-0.1847^{*} \\
(0.098)\end{array}$ & $\begin{array}{l}0.4839^{*} \\
(0.206)\end{array}$ \\
\hline Age $78-82$ & & & & & $\begin{array}{l}-0.2115^{*} \\
(0.110)\end{array}$ & $\begin{array}{l}0.6625^{* * *} \\
(0.191)\end{array}$ \\
\hline Age $83-87$ & & & & & $\begin{array}{l}-0.1106 \\
(0.154)\end{array}$ & $\begin{array}{l}0.7177^{*} \\
(0.324)\end{array}$ \\
\hline Age $88-108$ & & & & & $\begin{array}{l}-0.3627 \\
(0.359)\end{array}$ & $\begin{array}{l}0.5997^{* *} \\
(0.253)\end{array}$ \\
\hline Minimum & 48.8 & 35.4 & 42.9 & 36.6 & & \\
\hline Maximum & & & 82.4 & 93.8 & & \\
\hline $\mathrm{N}$ & 77527 & 17389 & 77527 & 17389 & 77527 & 17389 \\
\hline $\operatorname{Adj} . \mathrm{R}^{2}$ & 0.246 & 0.241 & 0.246 & 0.242 & 0.246 & 0.242 \\
\hline
\end{tabular}

Note. The dependent variable is self-rated individual life satisfaction (10-point scale). Age ranges from 18 to 108, with age 18-22 as the reference in (5) and (6). Controls are gender, employment status (full-time employed, part-time employed, self-employed, with not employed as the reference), marital status (married/living together, divorced/separated, widowed, with single/never married as the reference), education (medium level education and high level education, with low level education as the reference), income quintiles, self-reported health (5-point scale), country dummies, and year dummies. Robust standard errors clustered at the country level in parentheses; * $p<0.1$, $* * p<0.05, * * * p<0.01$. 

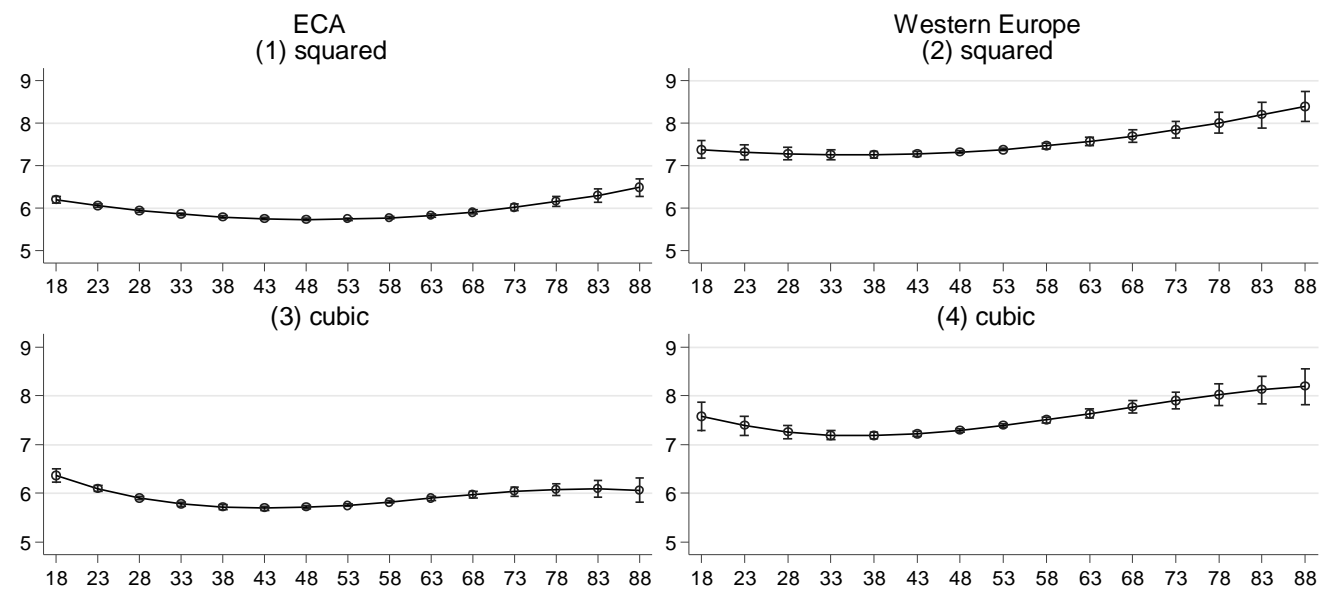

(5) non-parametric

(6) non-parametric
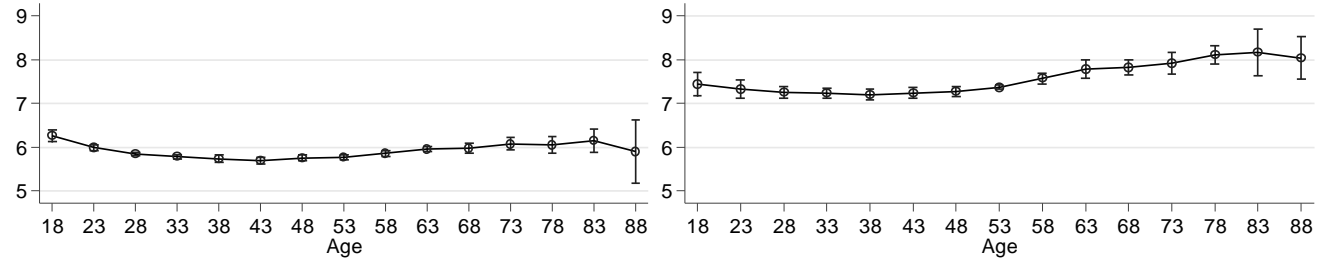

Note: The panel numbers correspond to the regressions in Table 1

Figure 1 Average marginal effects of subjective well-being over the lifespan: IVS data (1981-2009)

\subsection{Impact of cohort effects}

To disentangle the age-specific correlation with well-being from that of the cohort effect, we add indicators for birth decades to the above regressions. The results for the IVS data and regressions with individual controls are given in Table 2, which reveals that not all functional forms of age remain significant when we control for cohort effects. For instance, although the U-shape remains robust for the ECA countries in column (1), the squared specification for Western Europe (column 2) fails to reach significance for the linear term even though it remains jointly significant. This latter could imply that well-being increases throughout the lifespan. The cohort effects themselves take varying signs but mostly fail to reach significance. Moreover, a within-comparison of the cohort dummies reveals only small differences, with only those born in 1990 and after showing significantly higher well-being in ECA countries. 
The second pair of columns, regressions (3) and (4), illustrate the S-shape of well-being for ECA and Western European countries. Comparing these specifications (see Tables 1 and 2) reveals that the inclusion of cohort effects has only a small impact on the age coefficients: as minima and maxima move toward younger age, well-being levels become lower in older age, a pattern observable for both ECA countries and Western Europe. The non-functional form of age mostly mimics the cubic term (Figure 2, bottom panels): the age coefficients for ECA lose their significance after the late 50s, but those for Western Europe show only a small decrease from 18-22 until the early 40s. In line with the functional form, the point estimate for well-being appears to decline for Western Europeans in the oldest age group, even though it is not significantly different from that for the young reference group. Interestingly, the cohort dummies for the ECA region (column 5) are also not significant, except for the 1930 birth cohort, which experienced the deprivation related to World War II at a very young age. Most cohort dummies for Western Europe, in contrast, are significant and negative, pointing to the relatively higher well-being of those in the oldest cohort (born before 1919). ${ }^{14}$ The marginal effects in Figure 2 show quite constant well-being over time, with slight downturns in middle and old age.

The results without individual characteristics controls are shown in Table A3 of Appendix 1. We fail to find the U-shape for ECA countries due to the insignificance of age and its squared term. ${ }^{15}$ Nonetheless, the coefficients for the cubic term for ECA countries and Western Europe remain significant, even when introducing cohort effects dummies. Similar to the ECA model without cohort dummies, the well-being function steadily declines with age. The average marginal effects for the estimates of columns 1-6 are illustrated in Figure A2 of

\footnotetext{
${ }^{14}$ It should be noted, however, that the reference cohort (born before 1919) is a very select sample, not only because of their survival but also because their early years coincide with turbulent times (e.g., the 1917 October Revolution and WWI).

${ }^{15}$ Despite the insignificant age coefficients, a joined significance test and an alternative model with a linear specification for age suggests that well-being significantly decreases over the lifespan.
} 


\section{Appendix 1.}

To confirm the importance of cohort effects and their interplay with the age specification, we apply the same method used for the IVS data to the LiTS data set (age range of 18-99), although we cannot make direct comparisons between the ECA and Western Europe because the LiTS only covers ECA countries in more than one wave. The age pattern revealed by the LiTS results (Figure 3) is similar to that from the IVS with some noteworthy exceptions: First, the LiTS results for the cubic age specification provide little support for a second turning point in well-being, as maxima are estimated to be beyond normal life expectancy, and thus suggest a U-shape. Second, adding cohort dummies to the regressions has little effect on the age coefficients and the overall well-being pattern (see Appendix 1 Table A4). For the unconditional case (available upon request), we find similar changes to the ECA countries as in the IVS data. Even though the squared terms (with and without controlling for cohort effects) remain significant, the minimum is found between 60 s and 70 s, with little increase in well-being in old age. ${ }^{16}$

\footnotetext{
${ }^{16}$ We additionally test the sensitivity of our results to excluding self-rated health from the conditional regressions. The results (available upon request) are quantitatively similar to those in Table 1 and 2. Excluding self-rated health, however, tends to shift the minimum slightly to an older age, but moves the maximum to a younger one.
} 
Table 2 Well-being over the lifespan in ECA countries and Western Europe with cohort dummies: IVS data (1981-2009)

\begin{tabular}{|c|c|c|c|c|c|c|}
\hline & $\begin{array}{c}\text { ECA } \\
(1)\end{array}$ & $\begin{array}{c}\text { Western Europe } \\
\text { (2) }\end{array}$ & $\begin{array}{c}\text { ECA } \\
(3)\end{array}$ & $\begin{array}{c}\text { Western Europe } \\
\text { (4) }\end{array}$ & $\begin{array}{c}\text { ECA } \\
(5)\end{array}$ & $\begin{array}{c}\text { Western Europe } \\
\text { (6) }\end{array}$ \\
\hline Age & $-0.0413^{* * * *}$ & -0.0143 & $-0.1641^{* * * *}$ & $-0.1094^{* * * *}$ & & \\
\hline & $(0.009)$ & $(0.011)$ & $(0.027)$ & $(0.021)$ & & \\
\hline Age squared & $0.0004^{* * *}$ & $0.0002^{* *}$ & $0.0032^{* * *}$ & $0.0023^{* * *}$ & & \\
\hline & $(0.000)$ & $(0.000)$ & $(0.001)$ & $(0.001)$ & & \\
\hline Age cubic & & & $\begin{array}{l}-0.00002^{* * *} \\
(0.000)\end{array}$ & $\begin{array}{l}-0.00001^{* * * *} \\
(0.000)\end{array}$ & & \\
\hline Age $23-27$ & & & & & $\begin{array}{l}-0.2572^{* * * *} \\
(0.077)\end{array}$ & $\begin{array}{l}-0.1204^{*} \\
(0.059)\end{array}$ \\
\hline Age $28-32$ & & & & & $\begin{array}{l}-0.3884^{* * * *} \\
(0.084)\end{array}$ & $\begin{array}{l}-0.1453^{* * * *} \\
(0.036)\end{array}$ \\
\hline Age $33-37$ & & & & & $\begin{array}{l}-0.4387^{* * *} \\
(0.094)\end{array}$ & $\begin{array}{l}-0.1616^{*} \\
(0.085)\end{array}$ \\
\hline Age $38-42$ & & & & & $\begin{array}{l}-0.4219^{* * * *} \\
(0.140)\end{array}$ & $\begin{array}{l}-0.2211^{*} \\
(0.097)\end{array}$ \\
\hline Age 43-47 & & & & & $\begin{array}{l}-0.4410^{* * * *} \\
(0.133)\end{array}$ & $\begin{array}{l}-0.1955 \\
(0.115)\end{array}$ \\
\hline Age $48-52$ & & & & & $\begin{array}{l}-0.3163^{* *} \\
(0.139)\end{array}$ & $\begin{array}{l}-0.1898 \\
(0.161)\end{array}$ \\
\hline Age 53-57 & & & & & $\begin{array}{l}-0.2807^{* *} \\
(0.135)\end{array}$ & $\begin{array}{l}-0.0928 \\
(0.166)\end{array}$ \\
\hline Age $58-62$ & & & & & $\begin{array}{l}-0.1555 \\
(0.149)\end{array}$ & $\begin{array}{l}0.0375 \\
(0.239)\end{array}$ \\
\hline Age 63-67 & & & & & $\begin{array}{l}-0.0565 \\
(0.150)\end{array}$ & $\begin{array}{l}0.2371 \\
(0.230)\end{array}$ \\
\hline Age $68-72$ & & & & & $\begin{array}{l}-0.0462 \\
(0.165)\end{array}$ & $\begin{array}{l}0.1333 \\
(0.289)\end{array}$ \\
\hline Age 73-77 & & & & & $\begin{array}{l}0.0354 \\
(0.168)\end{array}$ & $\begin{array}{l}0.1932 \\
(0.263)\end{array}$ \\
\hline Age $78-82$ & & & & & $\begin{array}{l}-0.0820 \\
(0.168)\end{array}$ & $\begin{array}{l}0.3045 \\
(0.316)\end{array}$ \\
\hline Age $83-87$ & & & & & $\begin{array}{l}-0.0167 \\
(0.185)\end{array}$ & $\begin{array}{l}0.3564 \\
(0.339)\end{array}$ \\
\hline Age $88-108$ & & & & & $\begin{array}{l}-0.3394 \\
(0.381)\end{array}$ & $\begin{array}{l}-0.0005 \\
(0.448)\end{array}$ \\
\hline Born 1920-29 & $\begin{array}{l}0.1519 \\
(0.158)\end{array}$ & $\begin{array}{l}-0.1624 \\
(0.131)\end{array}$ & $\begin{array}{l}-0.1199 \\
(0.156)\end{array}$ & $\begin{array}{l}-0.2128 \\
(0.145)\end{array}$ & $\begin{array}{l}-0.1340 \\
(0.153)\end{array}$ & $\begin{array}{l}-0.3534^{* *} \\
(0.104)\end{array}$ \\
\hline Born 1930-39 & $\begin{array}{l}0.1258 \\
(0.171)\end{array}$ & $\begin{array}{l}-0.1557 \\
(0.120)\end{array}$ & $\begin{array}{l}-0.2635 \\
(0.169)\end{array}$ & $\begin{array}{l}-0.2632^{*} \\
(0.121)\end{array}$ & $\begin{array}{l}-0.2956^{*} \\
(0.162)\end{array}$ & $\begin{array}{l}-0.4217^{* *} \\
(0.146)\end{array}$ \\
\hline Born 1940-49 & $\begin{array}{l}0.1634 \\
(0.175)\end{array}$ & $\begin{array}{l}-0.2329 \\
(0.171)\end{array}$ & $\begin{array}{l}-0.2231 \\
(0.174)\end{array}$ & $\begin{array}{l}-0.3112 \\
(0.167)\end{array}$ & $\begin{array}{l}-0.2697 \\
(0.162)\end{array}$ & $\begin{array}{l}-0.6026^{\text {*** }} \\
(0.187)\end{array}$ \\
\hline Born 1950-59 & $\begin{array}{l}0.1275 \\
(0.189)\end{array}$ & $\begin{array}{l}-0.3656 \\
(0.208)\end{array}$ & $\begin{array}{l}-0.1604 \\
(0.189)\end{array}$ & $\begin{array}{l}-0.3650 \\
(0.223)\end{array}$ & $\begin{array}{l}-0.2130 \\
(0.179)\end{array}$ & $\begin{array}{l}-0.6670^{\text {*** }} \\
(0.276)\end{array}$ \\
\hline Born 1960-69 & $\begin{array}{l}0.1523 \\
(0.200)\end{array}$ & $\begin{array}{l}-0.3405 \\
(0.223)\end{array}$ & $\begin{array}{l}-0.0440 \\
(0.200)\end{array}$ & $\begin{array}{l}-0.2737 \\
(0.258)\end{array}$ & $\begin{array}{l}-0.0978 \\
(0.186)\end{array}$ & $\begin{array}{l}-0.6782^{*} \\
(0.318)\end{array}$ \\
\hline Born 1970-79 & $\begin{array}{l}0.2165 \\
(0.207)\end{array}$ & $\begin{array}{l}-0.2955 \\
(0.246)\end{array}$ & $\begin{array}{l}0.0208 \\
(0.208)\end{array}$ & $\begin{array}{l}-0.2218 \\
(0.294)\end{array}$ & $\begin{array}{l}-0.0181 \\
(0.204)\end{array}$ & $\begin{array}{l}-0.7127^{*} \\
(0.362)\end{array}$ \\
\hline Born 1980-89 & $\begin{array}{l}0.2319 \\
(0.209)\end{array}$ & $\begin{array}{l}-0.1342 \\
(0.263)\end{array}$ & $\begin{array}{l}-0.0196 \\
(0.214)\end{array}$ & $\begin{array}{l}-0.1471 \\
(0.290)\end{array}$ & $\begin{array}{l}-0.0483 \\
(0.220)\end{array}$ & $\begin{array}{l}-0.6181 \\
(0.418)\end{array}$ \\
\hline Born 1990-99 & $\begin{array}{l}0.5546^{* *} \\
(0.244) \\
\end{array}$ & $\begin{array}{l}-0.3161 \\
(0.381) \\
\end{array}$ & $\begin{array}{l}0.1843 \\
(0.255) \\
\end{array}$ & $\begin{array}{l}-0.4497 \\
(0.377) \\
\end{array}$ & $\begin{array}{l}0.2565 \\
(0.259) \\
\end{array}$ & $\begin{array}{l}-0.8493^{*} \\
(0.400) \\
\end{array}$ \\
\hline Minimum & 46.6 & 28.8 & 38.3 & 34.0 & & \\
\hline Maximum & & & 76.0 & 85.1 & & \\
\hline $\mathrm{N}$ & 77527 & 17389 & 77527 & 17389 & 77527 & 17389 \\
\hline Adj. $\mathrm{R}^{2}$ & 0.246 & 0.242 & 0.246 & 0.242 & 0.246 & 0.242 \\
\hline
\end{tabular}

Note. The dependent variable is self-rated individual life satisfaction (10-point scale). Age ranges from 18 to 108, with age 18-22 as the reference in (5) and (6). For the cohort dummies, the reference group is those born between 1881 and 1919. The controls are gender, employment status (full-time employed, part-time employed, self-employed, with not employed as the reference), marital status (married/living together, divorced/separated, widowed, with single/never married as the reference), education (medium level education and high level education, with low level education as the reference), income quintiles, self-reported health (5-point scale), country dummies, and year dummies. Robust standard errors clustered at the country level in parentheses; $* p<0.1, * * p<0.05, * * * p<0.01$. 


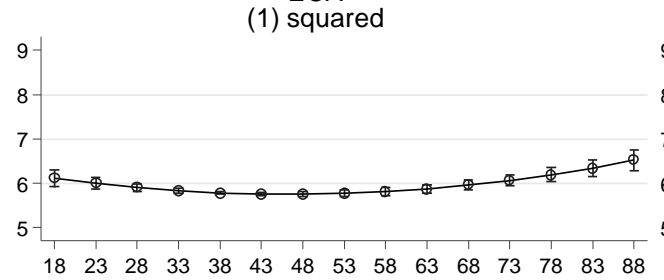

(2) squared

$\begin{array}{llllllllllllllllllllllllllllll}18 & 23 & 28 & 33 & 38 & 43 & 48 & 53 & 58 & 63 & 68 & 73 & 78 & 83 & 88 & 18 & 23 & 28 & 33 & 38 & 43 & 48 & 53 & 58 & 63 & 68 & 73 & 78 & 83 & 88\end{array}$ (3) cubic

(4) cubic
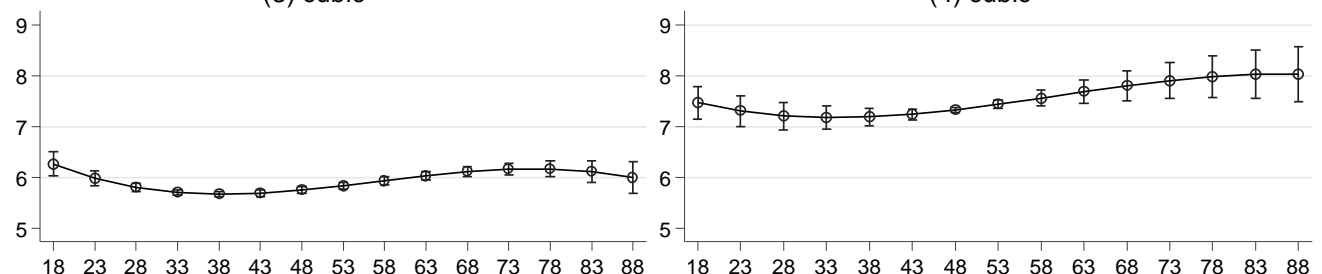

(5) non-parametric

(6) non-parametric

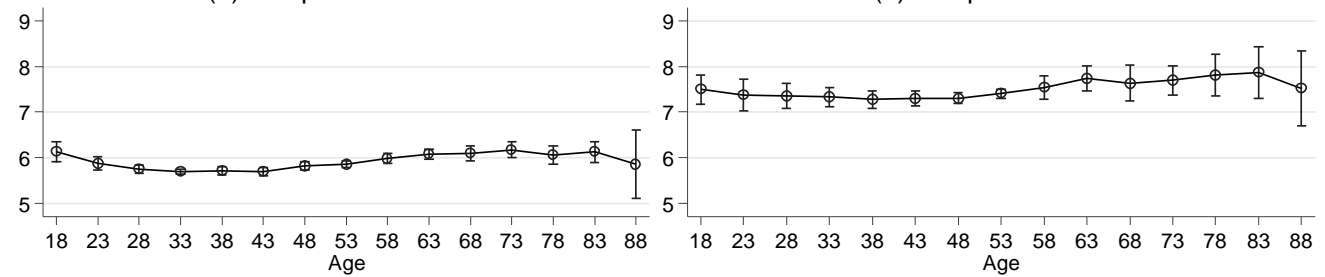

Note: The panel numbers correspond to the regressions in Table 2

Figure 2 Average marginal effects of subjective well-being over the lifespan with cohort dummies: IVS data

(1981-2009)

ECA

(1) squared

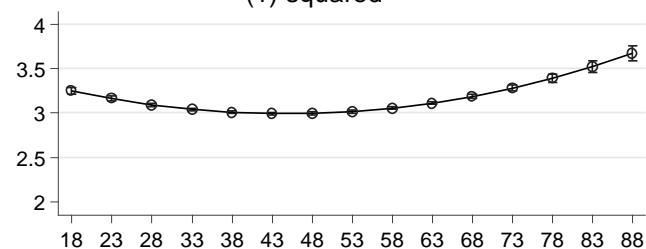

(3) cubic

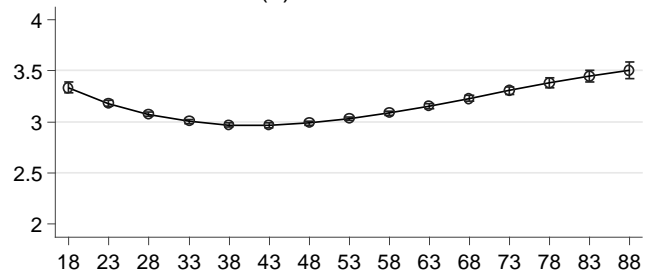

(5) non-parametric

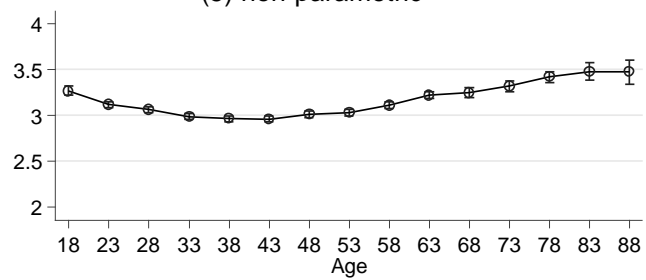

ECA with cohort dummies

(2) squared

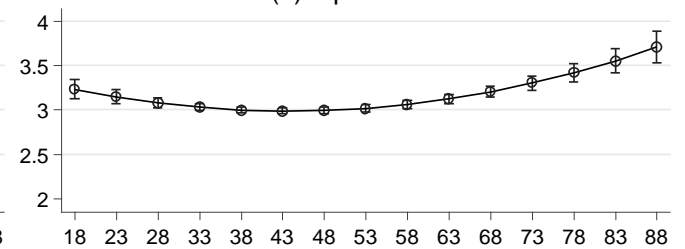

(4) cubic

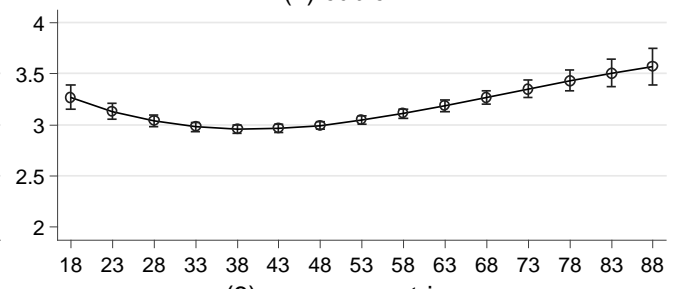

(6) non-parametric

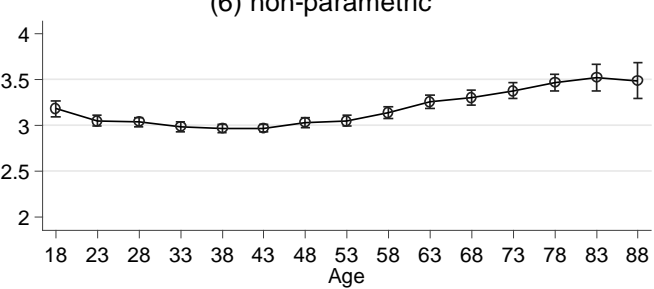

Figure 3 Average marginal effects of subjective well-being over the lifespan: LiTS data (2006-2010) 


\subsection{Well-being in a synthetic panel using LiTS}

To account for the time-constant effects shared by certain population groups, we construct a synthetic panel from the ECA countries in the LiTS data, whose results support the findings from the cross-sectional analysis (Table 3). Above all, once fixed-group effects and covariates are accounted for, the squared specification is highly significant, with a minimum at 59.3 (column 1), while the cubic term supports the U-shape until age 82.2, after which well-being decreases (column 3). However, as we exclude the oldest birth cohorts, the oldest individual in the sample is 80 , and we are therefore unable to reject either the U-shape or a second turning point. For the non-functional form, we see well-being to be lowest during the mid-50s and to recover afterwards. In the unconditional case, we still observe a U-shape in the squared model (column 2), but the cubic specification fails to provide evidence for an increase of well-being in old age - a finding mimicked by the non-parametric model. The corresponding marginal plots are provided in Appendix 1 Figure A3. 
Table 3 Well-being over the lifespan in a synthetic panel with group-fixed effects: LiTS data (2006-2010)

\begin{tabular}{|c|c|c|c|c|c|c|}
\hline & (1) & (2) & (3) & (4) & (5) & (6) \\
\hline Age & $\begin{array}{c}-0.0783^{* * * *} \\
(0.016)\end{array}$ & $\begin{array}{c}-0.0642^{* * * *} \\
(0.014)\end{array}$ & $\begin{array}{c}-0.1813^{* * * *} \\
(0.051)\end{array}$ & $\begin{array}{c}-0.0984^{* *} \\
(0.040)\end{array}$ & & \\
\hline Age squared & $\begin{array}{c}0.0007^{* * * *} \\
(0.000)\end{array}$ & $\begin{array}{c}0.0005^{* * *} \\
(0.000)\end{array}$ & $\begin{array}{c}0.0029^{* * *} \\
(0.001)\end{array}$ & $\begin{array}{l}0.0013 \\
(0.001)\end{array}$ & & \\
\hline Age cubic & & & $\begin{array}{c}-0.00001^{\text {*** }} \\
(0.000)\end{array}$ & $\begin{array}{c}-0.00005 \\
(0.000)\end{array}$ & & \\
\hline Age $23-27$ & & & & & $\begin{array}{r}-0.0074 \\
(0.076)\end{array}$ & $\begin{array}{c}-0.0716 \\
(0.082)\end{array}$ \\
\hline Age $28-32$ & & & & & $\begin{array}{l}-0.0625 \\
(0.093)\end{array}$ & $\begin{array}{c}-0.1843^{* * *} \\
(0.087)\end{array}$ \\
\hline Age $33-37$ & & & & & $\begin{array}{c}-0.1720 \\
(0.107)\end{array}$ & $\begin{array}{c}-0.2112^{*} \\
(0.120)\end{array}$ \\
\hline Age $38-42$ & & & & & $\begin{array}{c}-0.1914^{*} \\
(0.115)\end{array}$ & $\begin{array}{c}-0.2333^{\text {*** }} \\
(0.110)\end{array}$ \\
\hline Age $43-47$ & & & & & $\begin{array}{c}-0.2158^{*} \\
(0.119)\end{array}$ & $\begin{array}{c}-0.2962^{* * *} \\
(0.124)\end{array}$ \\
\hline Age $48-52$ & & & & & $\begin{array}{c}-0.3023^{* * *} \\
(0.128)\end{array}$ & $\begin{array}{c}-0.3853^{* * *} \\
(0.124)\end{array}$ \\
\hline Age 53-57 & & & & & $\begin{array}{c}-0.3460^{* * *} \\
(0.143)\end{array}$ & $\begin{array}{c}-0.4993^{* * * *} \\
(0.143)\end{array}$ \\
\hline Age $58-62$ & & & & & $\begin{array}{c}-0.2882^{* * *} \\
(0.137)\end{array}$ & $\begin{array}{c}-0.4532^{* * * *} \\
(0.132)\end{array}$ \\
\hline Age 63-67 & & & & & $\begin{array}{c}-0.2829^{*} \\
(0.148)\end{array}$ & $\begin{array}{c}-0.4741^{* * * *} \\
(0.143)\end{array}$ \\
\hline Age $68-72$ & & & & & $\begin{array}{r}-0.2359 \\
(0.154)\end{array}$ & $\begin{array}{c}-0.4481^{* * *} \\
(0.146)\end{array}$ \\
\hline Age $73-77$ & & & & & $\begin{array}{c}-0.2967^{*} \\
(0.161)\end{array}$ & $\begin{array}{c}-0.4518^{* * * *} \\
(0.156)\end{array}$ \\
\hline Age $78-80$ & & & & & $\begin{array}{l}-0.2687 \\
(0.182)\end{array}$ & $\begin{array}{c}-0.3850^{* * *} \\
(0.162)\end{array}$ \\
\hline Constant & $\begin{array}{c}2.7647^{* * * *} \\
(0.445)\end{array}$ & $\begin{array}{c}4.8243^{* * *} \\
(0.339)\end{array}$ & $\begin{array}{c}4.0854^{* * * *} \\
(0.728)\end{array}$ & $\begin{array}{c}5.2447^{\text {**** }} \\
(0.581)\end{array}$ & $\begin{array}{c}0.9390^{* * *} \\
(0.288)\end{array}$ & $\begin{array}{c}3.3957^{* * * *} \\
(0.099)\end{array}$ \\
\hline Covariates & Yes & No & Yes & No & Yes & No \\
\hline Minimum & 59.3 & 62.5 & $\begin{array}{l}51.3 \\
82 ?\end{array}$ & $\begin{array}{l}62.2 \\
93.4\end{array}$ & & \\
\hline $\begin{array}{l}\text { Maximum } \\
\mathrm{N} \text { (groups) }\end{array}$ & 672 & 672 & $\begin{array}{l}82.2 \\
672\end{array}$ & $\begin{array}{c}93.4 \\
672\end{array}$ & 672 & 672 \\
\hline Adj. $R^{2}$ & 0.285 & 0.085 & 0.293 & 0.086 & 0.263 & 0.033 \\
\hline
\end{tabular}

Note. Individuals are grouped by birth-year decades, country, gender, and survey year. The dependent variable is group average life satisfaction (5-point scale). Age ranges from 18 to 80, with age 14-22 as the reference in (5) and (6). The individual controls are group averages of marital status (married versus unmarried as the reference), selfreported health (5-point scale), education (medium level education and high level education, with low level education as the reference), income quintiles, and employment (employed versus not employed as the reference). Robust standard errors in parentheses; $* p<0.1, * * p<0.05, * * * p<0.01$. 


\subsection{Well-being in a panel data set for the Russian Federation}

The comprehensive RLMS panel data for the Russian Federation permit us to follow the same individuals over time and include individual fixed effects (Clark and Oswald, 2006; Clark, 2007; Gwozdz and Sousa-Poza, 2010). Because the first four RLMS waves are problematic and Wave 5 lacks important socio-demographic controls, for this analysis, we rely on RLMS rounds VI (1995) to XXI (2013). Given the long time period of the survey, and similar to the IVS, it would not be reasonable to omit the year dummies. Hence, we estimate the dummy specification for the fixed-effect model and compare the results to the cross-sectional results (Ferrer-i-Carbonell and Frijters, 2004). In Table 4, we compare the pooled OLS including cohort effects with the fixed-effects model (column 7). ${ }^{17}$ By comparing age quadratic, and cubic term, as well as a dummy specification (age range of 14-104), we are able to quantify the differences in the results produced by the two methods and thereby assess the robustness of the age pattern. ${ }^{18}$ For the conditional regressions, both specifications, the squared and cubic term, are significant and produce the usual U-shape and S-shape, respectively. The non-parametric results of the pooled OLS reveal a similar pattern, which seems to hold when including fixed effects. However, the U-shape is less pronounced and well-being increases earlier in age and becomes significantly higher in old age compared to the reference group aged 14 to $22 .{ }^{19}$

\footnotetext{
${ }^{17}$ As we do not include survey weights into the cross-sectional regressions, we followed the recommendation of Heeringa (1997) and re-estimated the models including dummies for the 176 areas to account for the non-random sampling procedure: the results remain robust and do not substantially differ from Table 4.

${ }^{18}$ Following the critic of De Ree and Alessie (2011) that the age pattern in the fixed-effects dummy regression is sensitive to the choice of the age bracket, we re-estimate the model with different age brackets ranging from 2 to 10 years. Smaller age brackets show a stronger increase in well-being over the lifecycle, while the minimum in mid-age becomes more pronounced when the brackets are large.

${ }^{19}$ We test the possibility of attrition bias in the RLMS data set by introducing the variable addition test proposed by Verbeek and Nijman (1992). Specifically, the test variable is a count of the number of surveyed waves that each respondent is present in the RLMS. We add this variable to the right side of equation (3). The test of attrition bias rests on the significance of this added variable, with insignificance implying no attrition bias. The results from the fixed-effects estimation indicate that attrition bias is not a serious issue in our analysis. Although the variable is significant, its inclusion neither affects significance of the age variable, nor does it shift the age minima and maxima by more than half a year.
} 
For the unconditional regressions, the results from the pooled OLS show little increase in old age and the cubic term (column 4) fails to depict a turning point. The non-parametric results also decrease with age and the lowest well-being is observed for the oldest group. When including individual fixed effects, we observe increasing well-being after the 30 s with a slight decrease for the oldest age group. For visual comparison, the corresponding average marginal effects for pooled OLS, as well as for the fixed-effects are plotted in Figure 4. 
Table 4 Comparison of well-being over the lifespan in the pooled OLS versus fixed-effects regressions:

RLMS data (1995-2013)

\begin{tabular}{|c|c|c|c|c|c|c|c|c|}
\hline & \multicolumn{6}{|c|}{ Pooled OLS } & \multicolumn{2}{|c|}{ Fixed-effects } \\
\hline & (1) & (2) & (3) & (4) & (5) & (6) & (7) & (8) \\
\hline Age & $\begin{array}{c}-0.0598 * * * \\
(0.003)\end{array}$ & $\begin{array}{c}-0.0329 * * * \\
(0.002)\end{array}$ & $\begin{array}{c}-0.1587 * * * \\
(0.006)\end{array}$ & $\begin{array}{c}-0.0726 * * * \\
(0.005)\end{array}$ & & & & \\
\hline Age squared & $\begin{array}{c}0.0006 * * * \\
(0.000)\end{array}$ & $\begin{array}{c}0.0002 * * * \\
(0.000)\end{array}$ & $\begin{array}{c}0.0028 * * * \\
(0.000)\end{array}$ & $\begin{array}{c}0.0012^{* * *} * \\
(0.000)\end{array}$ & & & & \\
\hline Age cubic & & & $\begin{array}{c}-0.00002^{* * * *} \\
(0.000)\end{array}$ & $\begin{array}{c}-0.00001 * * * \\
(0.000)\end{array}$ & & & & \\
\hline Age 23-27 & & & & & $\begin{array}{c}-0.3336 * * * \\
(0.018)\end{array}$ & $\begin{array}{c}-0.1716 * * * \\
(0.015)\end{array}$ & $\begin{array}{c}-0.1460 * * * \\
(0.020)\end{array}$ & $\begin{array}{c}-0.0725^{* * * *} \\
(0.017)\end{array}$ \\
\hline Age $28-32$ & & & & & $\begin{array}{c}-0.3939 * * * \\
(0.022)\end{array}$ & $\begin{array}{c}-0.2200 * * * \\
(0.020)\end{array}$ & $\begin{array}{c}-0.1255^{* * * *} \\
(0.027)\end{array}$ & $\begin{array}{r}-0.0208 \\
(0.024)\end{array}$ \\
\hline Age $33-37$ & & & & & $\begin{array}{c}-0.4426 * * * \\
(0.027)\end{array}$ & $\begin{array}{c}-0.2728 * * * \\
(0.026)\end{array}$ & $\begin{array}{c}-0.1336 * * * \\
(0.033)\end{array}$ & $\begin{array}{l}0.0078 \\
(0.030)\end{array}$ \\
\hline Age $38-42$ & & & & & $\begin{array}{c}-0.4463 * * * \\
(0.032)\end{array}$ & $\begin{array}{c}-0.3005 * * * \\
(0.032)\end{array}$ & $\begin{array}{c}-0.0731^{*} \\
(0.040)\end{array}$ & $\begin{array}{c}0.0843 * * \\
(0.037)\end{array}$ \\
\hline Age $43-47$ & & & & & $\begin{array}{c}-0.4382 * * * \\
(0.038)\end{array}$ & $\begin{array}{c}-0.3292 * * * \\
(0.038)\end{array}$ & $\begin{array}{l}0.0013 \\
(0.047)\end{array}$ & $\begin{array}{c}0.1656^{* * * *} \\
(0.044)\end{array}$ \\
\hline Age $48-52$ & & & & & $\begin{array}{c}-0.4157 * * * \\
(0.044)\end{array}$ & $\begin{array}{c}-0.3579 * * * \\
(0.044)\end{array}$ & $\begin{array}{l}0.0657 \\
(0.054)\end{array}$ & $\begin{array}{c}0.2294 * * * * \\
(0.050)\end{array}$ \\
\hline Age 53-57 & & & & & $\begin{array}{c}-0.3154 * * * \\
(0.050)\end{array}$ & $\begin{array}{c}-0.3301 * * * \\
(0.051)\end{array}$ & $\begin{array}{c}0.1971 * * * \\
(0.061)\end{array}$ & $\begin{array}{c}0.3540 * * * \\
(0.057)\end{array}$ \\
\hline Age $58-62$ & & & & & $\begin{array}{c}-0.2106 * * * \\
(0.055)\end{array}$ & $\begin{array}{c}-0.3281 * * * \\
(0.056)\end{array}$ & $\begin{array}{c}0.3401 * * * \\
(0.068)\end{array}$ & $\begin{array}{c}0.4497 \text { *** } \\
(0.064)\end{array}$ \\
\hline Age $63-67$ & & & & & $\begin{array}{c}-0.1469^{* *} \\
(0.062)\end{array}$ & $\begin{array}{c}-0.3845 * * * \\
(0.063)\end{array}$ & $\begin{array}{c}0.4118 \text { *** } \\
(0.075)\end{array}$ & $\begin{array}{c}0.4681^{* * * *} \\
(0.070)\end{array}$ \\
\hline Age $68-72$ & & & & & $\begin{array}{r}-0.0381 \\
(0.068)\end{array}$ & $\begin{array}{c}-0.3902 * * * \\
(0.070)\end{array}$ & $\begin{array}{c}0.5069 * * * \\
(0.083)\end{array}$ & $\begin{array}{c}0.5120 * * * \\
(0.078)\end{array}$ \\
\hline Age $73-77$ & & & & & $\begin{array}{l}0.0395 \\
(0.075)\end{array}$ & $\begin{array}{c}-0.4052 * * * \\
(0.077)\end{array}$ & $\begin{array}{c}0.5888^{* * * *} \\
(0.091)\end{array}$ & $\begin{array}{c}0.5442 * * * \\
(0.085)\end{array}$ \\
\hline Age $78-82$ & & & & & $\begin{array}{l}0.1222 \\
(0.082)\end{array}$ & $\begin{array}{c}-0.4235 * * * \\
(0.084)\end{array}$ & $\begin{array}{c}0.6661 * * * \\
(0.099)\end{array}$ & $\begin{array}{c}0.5574 * * * \\
(0.093)\end{array}$ \\
\hline Age $83-87$ & & & & & $\begin{array}{c}0.2481 \text { *** } \\
(0.092)\end{array}$ & $\begin{array}{c}-0.3526 * * * \\
(0.094)\end{array}$ & $\begin{array}{c}0.7907 * * * \\
(0.110)\end{array}$ & $\begin{array}{c}0.6608 * * * \\
(0.104)\end{array}$ \\
\hline Age $88-108$ & & & & & $\begin{array}{l}0.1628 \\
(0.108)\end{array}$ & $\begin{array}{c}-0.4893 * * * \\
(0.113)\end{array}$ & $\begin{array}{c}0.7074 * * * \\
(0.135)\end{array}$ & $\begin{array}{c}0.5275^{* * * *} \\
(0.130)\end{array}$ \\
\hline Born 1920-29 & $\begin{array}{l}0.0510 \\
(0.052)\end{array}$ & $\begin{array}{c}-0.1168 * * \\
(0.051)\end{array}$ & $\begin{array}{c}-0.2166 * * * \\
(0.052)\end{array}$ & $\begin{array}{c}-0.2314 * * * \\
(0.052)\end{array}$ & $\begin{array}{c}-0.1055^{* *} \\
(0.051)\end{array}$ & $\begin{array}{c}-0.1160 * * \\
(0.051)\end{array}$ & & \\
\hline Born 1930-39 & $\begin{array}{l}0.0410 \\
(0.059)\end{array}$ & $\begin{array}{c}-0.1692 * * * \\
(0.059)\end{array}$ & $\begin{array}{c}-0.3273 * * * \\
(0.060)\end{array}$ & $\begin{array}{c}-0.3271 \text { *** } \\
(0.060)\end{array}$ & $\begin{array}{c}-0.1559 * * * \\
(0.057)\end{array}$ & $\begin{array}{c}-0.1529 * * * \\
(0.057)\end{array}$ & & \\
\hline Born 1940-49 & $\begin{array}{l}-0.0106 \\
(0.071)\end{array}$ & $\begin{array}{c}-0.1881 * * * \\
(0.071)\end{array}$ & $\begin{array}{c}-0.3737 * * * \\
(0.072)\end{array}$ & $\begin{array}{c}-0.3401 * * * \\
(0.073)\end{array}$ & $\begin{array}{c}-0.1739 * * * \\
(0.065)\end{array}$ & $\begin{array}{c}-0.1407 * * \\
(0.066)\end{array}$ & & \\
\hline Born 1950-59 & $\begin{array}{c}-0.0866 \\
(0.082)\end{array}$ & $\begin{array}{c}-0.2442 * * * \\
(0.084)\end{array}$ & $\begin{array}{c}-0.3640 * * * \\
(0.083)\end{array}$ & $\begin{array}{c}-0.3531 \text { **** } \\
(0.084)\end{array}$ & $\begin{array}{c}-0.1398 * \\
(0.073)\end{array}$ & $\begin{array}{c}-0.1189 \\
(0.074)\end{array}$ & & \\
\hline Born 1960-69 & $\begin{array}{c}-0.1776^{*} \\
(0.095)\end{array}$ & $\begin{array}{c}-0.3035 * * * \\
(0.097)\end{array}$ & $\begin{array}{c}-0.3566 * * * \\
(0.094)\end{array}$ & $\begin{array}{c}-0.3634 * * * \\
(0.097)\end{array}$ & $\begin{array}{c}-0.1028 \\
(0.082)\end{array}$ & $\begin{array}{c}-0.0776 \\
(0.084)\end{array}$ & & \\
\hline Born 1970-79 & $\begin{array}{c}-0.2175^{* *} \\
(0.107)\end{array}$ & $\begin{array}{c}-0.2989 * * * \\
(0.110)\end{array}$ & $\begin{array}{c}-0.3586^{* * *} * \\
(0.106)\end{array}$ & $\begin{array}{c}-0.3377 \text { *** } \\
(0.110)\end{array}$ & $\begin{array}{l}-0.0207 \\
(0.092)\end{array}$ & $\begin{array}{l}0.0201 \\
(0.094)\end{array}$ & & \\
\hline Born 1980-89 & $\begin{array}{c}-0.2100 * \\
(0.119)\end{array}$ & $\begin{array}{c}-0.2933^{* *} \\
(0.123)\end{array}$ & $\begin{array}{c}-0.4103 * * * \\
(0.118)\end{array}$ & $\begin{array}{c}-0.3550 \text { *** } \\
(0.123)\end{array}$ & $\begin{array}{l}0.0523 \\
(0.101)\end{array}$ & $\begin{array}{l}0.0910 \\
(0.103)\end{array}$ & & \\
\hline Born 1990-99 & $\begin{array}{r}-0.0765 \\
(0.130)\end{array}$ & $\begin{array}{c}-0.2555^{*} \\
(0.135)\end{array}$ & $\begin{array}{c}-0.3857 * * * \\
(0.129)\end{array}$ & $\begin{array}{c}-0.3610^{* * * *} \\
(0.135)\end{array}$ & $\begin{array}{c}0.2003^{*} \\
(0.108)\end{array}$ & $\begin{array}{c}0.1838 * \\
(0.112)\end{array}$ & & \\
\hline Covariates & Yes & No & Yes & No & Yes & No & Yes & No \\
\hline Minimum & 51.7 & 78.7 & 42.4 & N/A & & & & \\
\hline Maximum & & & 82.5 & N/A & & & & \\
\hline $\mathrm{N}$ & 162808 & 192084 & 162808 & 192084 & 162808 & 192084 & 162808 & 192084 \\
\hline $\operatorname{Adj} . \mathrm{R}^{2}$ & 0.205 & 0.138 & 0.208 & 0.139 & 0.204 & 0.138 & 0.088 & 0.062 \\
\hline
\end{tabular}



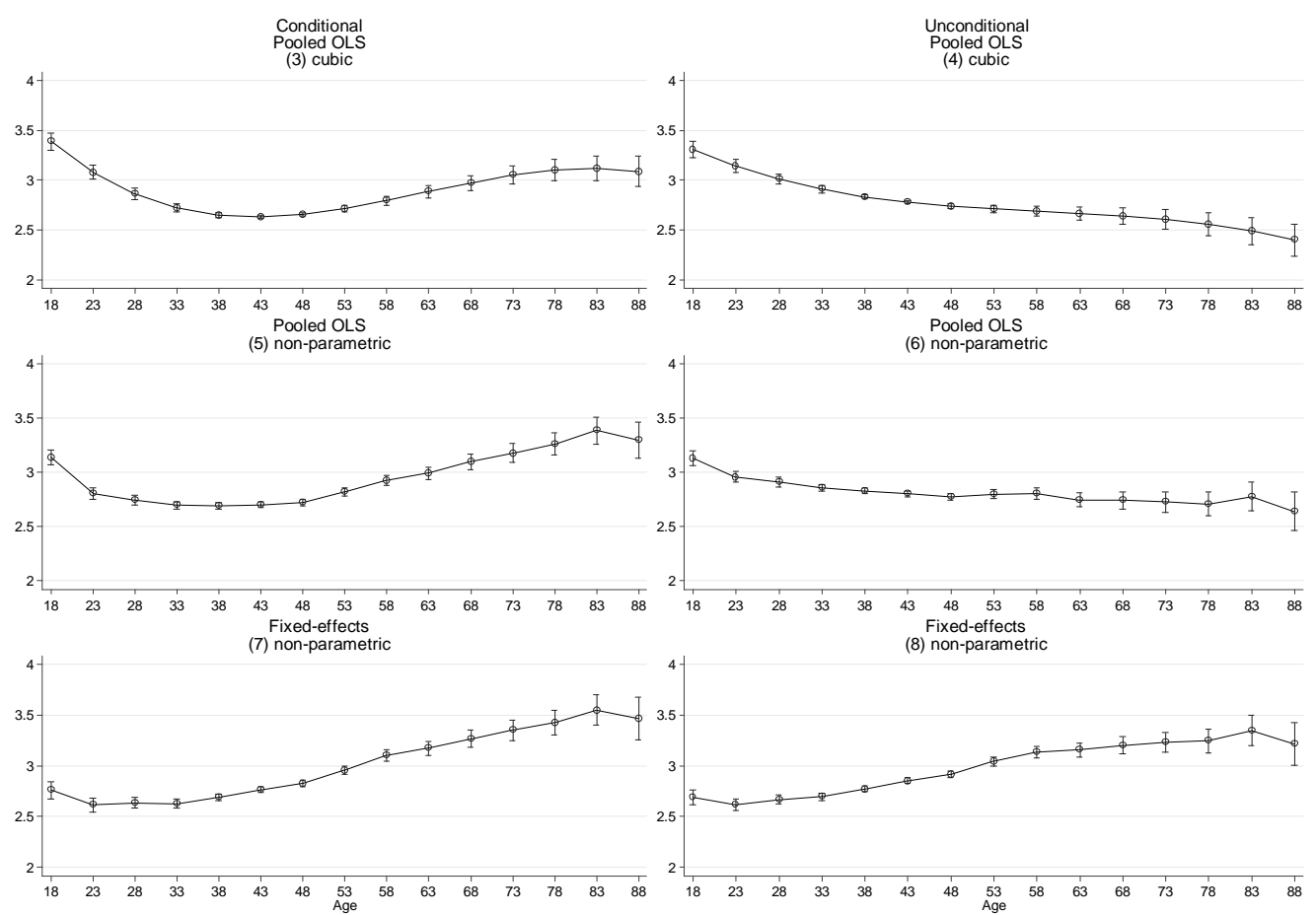

Note: The panel numbers correspond to the regressions in Table 4

Figure 4. Average marginal effects of a methodical and gender comparison of well-being over the lifespan:

RLMS data (1995-2013)

\subsection{Country-specific differences in ECA countries}

To test whether the results described above hold within the diverse ECA sample, we conclude by conducting country-specific analysis using the LiTS data, which covers most relevant countries in two waves. The results, shown in Table 5, produce a heterogeneous picture, with 17 countries exhibiting an S-shaped relation between age and well-being. For all other countries, the cubic term is insignificant, but the squared-term specification yields significant coefficients, suggesting a U-shape relation; a heterogeneity also evident from the variation in minima (32.9 to 51.3) and maxima (67.4 to 101.8$)$. The similar cross-country comparison for the unconditional case shows only five countries with a S-shape (Appendix 1 Table A5). The U-shape holds for the majority of countries, even though the minimum appears late in life (54.0 to 86.7). For eight countries, however, the results support neither minimum nor maximum. 
Table 5 Country-specific differences of life satisfaction in age minima and maxima: LiTS data (2006-2010)

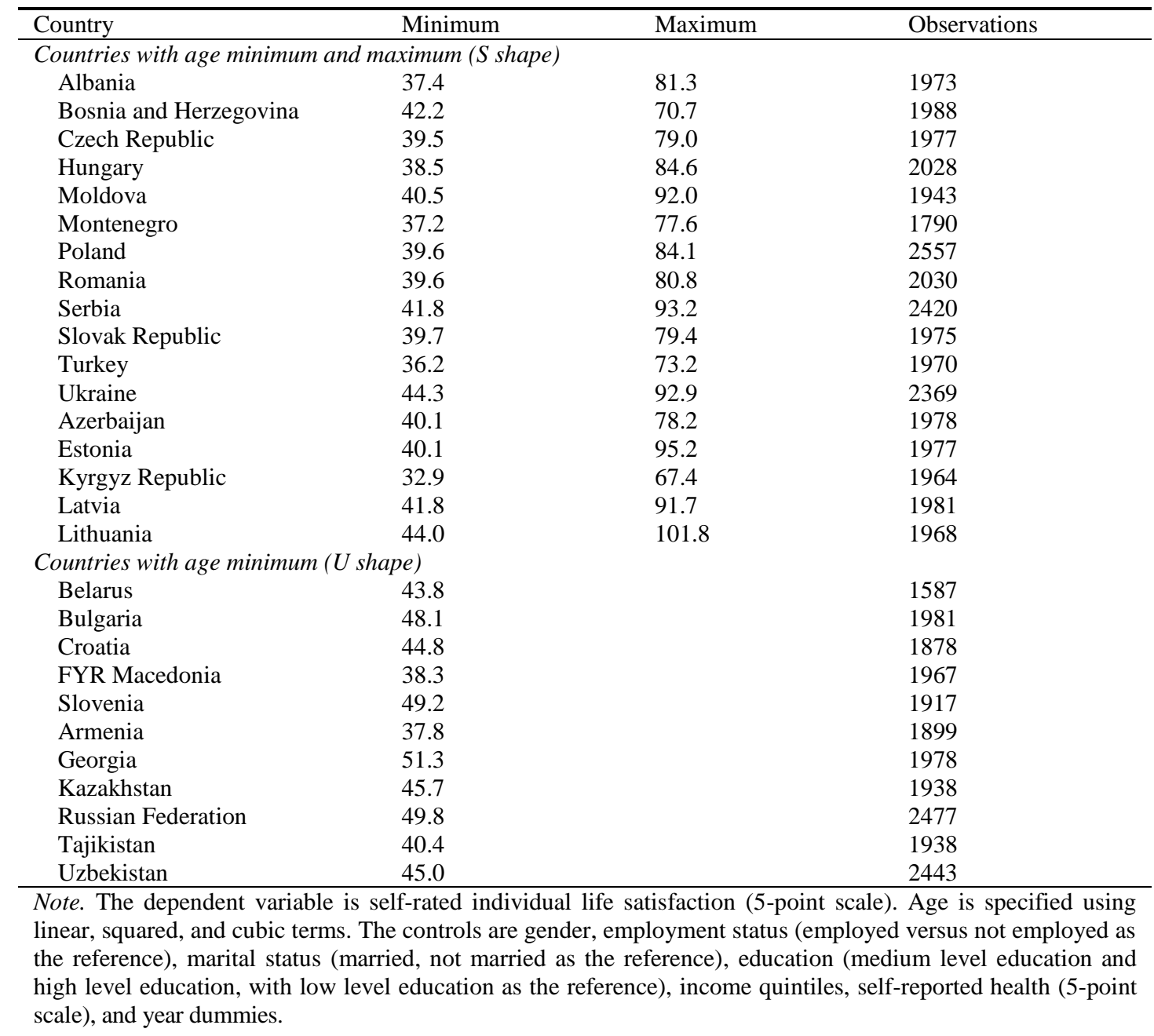

\section{Conclusions}

This analysis of the relation between age and well-being in Europe and Central Asia (ECA) takes advantage of panel and cross-sectional data from three large surveys: the Integrated Values Survey (IVS), the Life in Transition Survey (LiTS), and the Russia Longitudinal Monitoring Survey (RLMS). By focusing on the ECA region, the analysis makes two important contributions. First, by expanding the current research focus on high-income countries, it is better able to assess the universality of the U-shaped relation identified for Western countries. Second, it is able to leverage the disparate impacts of recent political and 
economic transformation in most ECA countries on the well-being of different cohorts to address the methodological problem of distinguishing between age and cohort effects. As Frijters and Beatton (2012) point out, the ideal would be to 'follow representative individuals throughout their whole life, starting at birth' (p. 529), but such data are not available. We partly overcome this limitation by examining well-being across the lifespan in a synthetic panel data set for ECA countries and a true panel data set for the Russian Federation. ${ }^{20} \mathrm{We}$ hypothesize that if a U-shape is observable in societies that have witnessed dramatic economic and social changes in past decades then, once cohort effects are corrected for (albeit imperfectly), they are most probably not the explanation for any observed U-shaped relation. In the aggregate, our findings mostly support the existence of a U-shape in individual wellbeing in the ECA up until the 70s and 80s but point to an apparent decrease in well-being among the oldest old, even after we control for self-reported health. This pattern remains robust for most of our cross-sectional and panel analyses, although within the ECA, there is significant heterogeneity in the pattern of well-being across the lifespan. However, if we look at the unconditional pattern, we obtain different results for the two samples. While the Ushape remains stable in Western Europe, well-being seems to mostly decline over the lifespan in the ECA countries.

\footnotetext{
${ }^{20}$ In the absence of large-scale panels that follow the same individuals across their lifespan, the most promising way to address the cohort issue is most probably by using less subjective measures of well-being such as in Weiss et al.'s (2012) ape study.
} 


\section{References}

Baetschmann, G. (2014). 'Heterogeneity in the relationship between happiness and age: Evidence from the German Socio-Economic Panel', German Economic Review, 15(3), pp. 393-410.

Blanchflower, D. G. and Oswald, A. J. (2008). 'Is well-being U-shaped over the life cycle?', Social Science \& Medicine, 66(8), pp. 1733-1749.

Blanchflower, D. G. and Oswald, A. J. (2011). 'Antidepressants and age', IZA Discussion Paper No. 5785.

Bussolo, M.; Koettl, J.; Sinnott, E. (2015). 'Golden Aging: Prospects for Healthy, Active, and Prosperous Aging in Europe and Central Asia.' Washington, DC: World Bank.

Clark, A. (2007), 'Born to be mild? Cohort effects don't (fully) explain why well-being is UShaped in age', IZA Discussion Paper No. 3170.

Clark, A. and Oswald, A. J. (2006), 'The curved relationship between subjective well-being and age', Paris-Jourdan Sciences Economiques Working Paper No. 29, Paris School of Economics.

Cojocaru, A. and Diagne, M. F. (2015). 'How reliable and consistent are subjective measures of welfare in Europe and Central Asia?' Economics of Transition, 23(1), pp. 75-103.

Deaton, A. (1985). 'Panel data from time series of cross-sections', Journal of Econometrics, 30(1-2), pp. 109-126.

Deaton, A. (2008). 'Income, health, and well-being around the world: Evidence from the Gallup World Poll', Journal of Economic Perspectives, 22(2), pp. 53-72.

De Ree, J and Alessie, R. (2011). 'Life satisfaction and age: Dealing with underidentification in age-period-cohort models'. Social Science \& Medicine, 73(1), pp. 177-182.

Devereux, P. J. (2007). 'Small-sample bias in synthetic cohort models of labour supply', Journal of Applied Econometrics, 22(4), pp. 839-848.

Easterlin, R. (2016). 'Paradox lost?', IZA Discussion Paper No. 9676.

Easterlin, R. (2006). 'Life cycle happiness and its sources: Intersections of psychology, economics, and demography', Journal of Economic Psychology, 27(4), pp. 463-482.

Ferrer-i-Carbonell, A. and Frijters, P. (2004). 'How important is the methodology for the estimates of determinants of happiness?' Economic Journal, 114(497), pp. 641--659.

Fischer, J. A. (2009). 'Happiness and age cycles-return to start...? On the functional relationship between subjective well-being and age', OECD Social, Employment and Migration Paper No. 99, OECD Publishing.

Frijters, P. and Beatton, T. (2012). 'The mystery of the U-shaped relationship between happiness and age', Journal of Economic Behavior and Organization, 82(2-3), pp. 525542. 
Frijters, P., Geishecker, I., Hasken-DeNew J. P., and Shields, M. A. (2006). 'Can the large swings in Russian life satisfaction be explained by ups and downs in real incomes?' Scandinavian Journal of Economics, 108(3), pp. 433-458.

Glenn, N. (2009). 'Is the apparent U-shape of well-being over the life course a result of inappropriate use of control variables? A commentary on Blanchflower and Oswald (66: 8, 2008, 1733-1749)'. Social Science \& Medicine, 69(4), pp. 481-485.

Graham, C., Eggers, A., and Skhtankar, S. (2004). 'Does happiness pay? An exploration based on panel data from Russia', Journal of Economic Behavior and Organization, 55(3), pp. 319-342.

Graham, C. and Pettinato S. (2002). 'Frustrated achievers: Winners, losers and subjective well-being in new market economies', Journal of Development Studies, 38(4), pp. 100140 .

Gwozdz, W. and Sousa-Poza, A. (2010). 'Ageing, health and life satisfaction of the oldest old: An analysis for Germany', Social Indicators Research, 97(3), pp. 397-417.

Hayo, B. (2007). 'Happiness in transition: An empirical study on Eastern Europe', Economic Systems, 31(2), pp. 204-221.

Hayo, B. and Seifert, W. (2003). 'Subjective economic well-being in Eastern Europe', Journal of Economic Psychology, 24(3), pp. 329-348.

Heeringa, S. G. (1997).'Russia Longitudinal Monitoring Survey (RLMS) Sample Attrition, Replenishment, and Weighting in Rounds V-VII', Available at: http://www.cpc.unc.edu/ projects/rlms-hse/project/samprep/samprep.pdf

Hellevik, O. (2015). 'The U-shaped age-happiness relationship: real or methodological artifact?', Quality \& Quantity, pp.1-21.

Kassenboehmer, S. C. and Haisken-DeNew, J. P. (2012). 'Heresy or enlightenment? The well-being age U-shape effect is flat', Economics Letters, 117(1), pp. 235-238.

Lopez Ulloa, B. F., Moller, V., and Sousa-Poza, A. (2013). 'How does subjective well-being evolve with age? A literature review', Journal of Population Ageing, 6(3), pp. 227-246.

Massin, S. and Kopp, P. (2014). 'Is life satisfaction hump-shaped with alcohol consumption?

Evidence from Russian panel data', Addictive Behaviors, 39(4), pp. 803-810.

Namazie, C. and Sanfey, P. (2001). 'Happiness in transition: The case of Kyrgyzstan', Review of Development Economics, 5(3), pp. 392-405.

Ravallion, M. and Lokshin, M. (2002). 'Self-rated economic welfare in Russia', European Economic Review, 46(8), pp. 1452-1473.

Realo, A. and Dobewall, H. (2011). 'Does life satisfaction change with age? A comparison of Estonia, Finland, Latvia, and Sweden', Journal of Research in Personality, 45 (3), pp. 297-308.

Russell, J. E. and Fraas, J. W. (2005). 'An application of panel regression to pseudo panel data', Multiple Linear Regression Viewpoints, 31(1), pp. 1-15. 
Steptoe, A., Deaton, A., and Stone, A. A. (2015). 'Subjective wellbeing, health, and ageing', Lancet, 385(9968), pp. 640-648.

Van Landeghem, B. (2008). 'Human well-being over the life cycle: Longitudinal evidence from a 20-year panel', LICOS Discussion Paper No. 213/2008, Catholic University, Leuven.

Van Landeghem, B. (2012). 'A test for the convexity of human well-being over the life cycle: Longitudinal evidence from a 20-year panel', Journal of Economic Behavior and Organization, 81(2), pp. 571-582.

Verbeek, M. and Nijman, T. (1993). 'Minimum MSE estimation of a regression model with fixed effects from a series of cross-sections', Journal of Econometrics, 59(1-2), pp. 125136.

Verbeek, M. and Nijman, T. (1992). 'Testing for selectivity bias in panel data models', International Economic Review, 33(3), pp. 681-703.

Weiss, A., King, J. E., Inoue-Murayama, M., Matsuzawa, T., and Oswald, A. J. (2012). 'Evidence for a midlife crisis in great apes consistent with the U-shape in human wellbeing', Proceedings of the National Academy of Sciences, 109(49), pp. 19,949-19,952. 


\section{Appendix 1: Additional Tables and Graphs}

Table A1 Descriptive statistics

\begin{tabular}{|c|c|c|c|c|c|}
\hline \multicolumn{2}{|l|}{ IVS } & \multicolumn{2}{|l|}{ LiTS } & \multicolumn{2}{|l|}{ RLMS } \\
\hline Variable & Mean & Variable & Mean & Variable & Mean \\
\hline Well-being & 5.876 & Well-being & 3.101 & Well-being & 2.865 \\
\hline Scales of well-being & $1-10$ & Scales of well-being & $1-5$ & Scales of well-being & $1-5$ \\
\hline Age & 43.878 & Age & 46.070 & Age & 45.093 \\
\hline Male & 0.456 & Male & 0.399 & Male & 0.424 \\
\hline \multicolumn{6}{|c|}{ Employment } \\
\hline Unemployed & 0.119 & Yes & 0.455 & Yes & 0.545 \\
\hline Other & 0.382 & & & & \\
\hline Part time & 0.051 & & & & \\
\hline Full time & 0.383 & & & & \\
\hline Self employed & 0.064 & & & & \\
\hline \multicolumn{6}{|c|}{ Marital status } \\
\hline Single & 0.200 & Married & 0.574 & Single & 0.169 \\
\hline Married & 0.641 & & & Married/living together & 0.602 \\
\hline Divorced & 0.059 & & & Divorced/separated & 0.098 \\
\hline Widowed & 0.100 & & & Widowed & 0.131 \\
\hline \multicolumn{6}{|c|}{ Education } \\
\hline Low & 0.358 & Low & 0.186 & Low & 0.407 \\
\hline Medium & 0.427 & Medium & 0.626 & Medium & 0.380 \\
\hline High & 0.215 & High & 0.188 & High & 0.212 \\
\hline Health & 3.488 & Health & 3.389 & Health & 3.142 \\
\hline Observations & 77,527 & 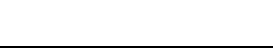 & 57,950 & (person/year) & 162,808 \\
\hline
\end{tabular}


Table A2 OLS estimates for ECA countries and Western Europe: IVS data (1981-2009, without individual controls)

\begin{tabular}{|c|c|c|c|c|c|c|}
\hline & $\begin{array}{c}(1) \\
\text { ECA }\end{array}$ & $\begin{array}{c}\text { (2) } \\
\text { Western Europe }\end{array}$ & $\begin{array}{c}(3) \\
\text { ECA }\end{array}$ & $\begin{array}{c}\text { (4) } \\
\text { Western Europe }\end{array}$ & $\begin{array}{c}(5) \\
\mathrm{ECA}\end{array}$ & $\begin{array}{c}(6) \\
\text { Western Europe }\end{array}$ \\
\hline Age & $\begin{array}{c}-0.04165^{* * *} \\
(0.005)\end{array}$ & $\begin{array}{c}-0.01803^{* *} \\
(0.006)\end{array}$ & $\begin{array}{c}-0.10605^{* * *} \\
(0.014)\end{array}$ & $\begin{array}{c}-0.05701^{* *} \\
(0.017)\end{array}$ & & \\
\hline Age squared & $\begin{array}{l}0.00024^{* * *} \\
(0.000)\end{array}$ & $\begin{array}{c}0.00018^{* *} \\
(0.000)\end{array}$ & $\begin{array}{c}0.00169^{* * * *} \\
(0.000)\end{array}$ & $\begin{array}{l}0.00103^{* *} \\
(0.000)\end{array}$ & & \\
\hline Age cubic & & & $\begin{array}{c}-0.00001^{* * * *} \\
(0.000)\end{array}$ & $\begin{array}{c}-0.00001^{* *} \\
(0.000)\end{array}$ & & \\
\hline Age $23-27$ & & & & & $\begin{array}{c}-0.24181^{* * *} \\
(0.050)\end{array}$ & $\begin{array}{c}-0.12325^{* * *} \\
(0.030)\end{array}$ \\
\hline Age $28-32$ & & & & & $\begin{array}{c}-0.39351^{* * * *} \\
(0.043)\end{array}$ & $\begin{array}{c}-0.07707^{*} \\
(0.036)\end{array}$ \\
\hline Age $33-37$ & & & & & $\begin{array}{c}-0.51722^{* * *} \\
(0.052)\end{array}$ & $\begin{array}{c}-0.10869^{*} \\
(0.049)\end{array}$ \\
\hline Age $38-42$ & & & & & $\begin{array}{c}-0.65364^{* * * *} \\
(0.069)\end{array}$ & $\begin{array}{c}-0.15245^{*} \\
(0.080)\end{array}$ \\
\hline Age 43-47 & & & & & $\begin{array}{c}-0.75278^{* * *} \\
(0.070)\end{array}$ & $\begin{array}{c}-0.21973^{* *} \\
(0.067)\end{array}$ \\
\hline Age 48-52 & & & & & $\begin{array}{c}-0.80258^{* * * *} \\
(0.074)\end{array}$ & $\begin{array}{c}-0.35193^{* *} \\
(0.101)\end{array}$ \\
\hline Age 53-57 & & & & & $\begin{array}{c}-0.91519^{* * *} \\
(0.079)\end{array}$ & $\begin{array}{c}-0.31517^{* *} \\
(0.104)\end{array}$ \\
\hline Age 58-62 & & & & & $\begin{array}{c}-0.84369^{* * *} \\
(0.088)\end{array}$ & $\begin{array}{c}-0.08927 \\
(0.087)\end{array}$ \\
\hline Age $63-67$ & & & & & $\begin{array}{c}-0.94135^{* * *} \\
(0.092)\end{array}$ & $\begin{array}{c}0.04931 \\
(0.078)\end{array}$ \\
\hline Age $68-72$ & & & & & $\begin{array}{c}-1.04263^{* * *} \\
(0.118)\end{array}$ & $\begin{array}{c}-0.04372 \\
(0.067)\end{array}$ \\
\hline Age 73-77 & & & & & $\begin{array}{c}-1.16237^{* * * *} \\
(0.107)\end{array}$ & $\begin{array}{c}-0.11416 \\
(0.114)\end{array}$ \\
\hline Age 78-82 & & & & & $\begin{array}{c}-1.26441^{* * * *} \\
(0.120)\end{array}$ & $\begin{array}{c}-0.15358 \\
(0.083)\end{array}$ \\
\hline Age $83-87$ & & & & & $\begin{array}{c}-1.34591^{* * *} \\
(0.148)\end{array}$ & $\begin{array}{c}-0.13316 \\
(0.132)\end{array}$ \\
\hline Age 88-108 & & & & & $\begin{array}{c}-1.54628^{* * *} \\
(0.332)\end{array}$ & $\begin{array}{c}-0.11838 \\
(0.167)\end{array}$ \\
\hline Minimum & 86.7 & 50.1 & N/A & 42.2 & & \\
\hline Maximum & & & N/A & 79.1 & & \\
\hline$N$ & 128690 & 44432 & 128690 & 44432 & 128690 & 44432 \\
\hline $\operatorname{Adj.} R^{2}$ & 0.129 & 0.058 & 0.130 & 0.058 & 0.130 & 0.060 \\
\hline
\end{tabular}

Note: The dependent variable is self-rated individual life satisfaction (10-point scale). Age ranges from 18 to 108 , with age 18-22 as the reference in (5) and (6). Controls are country dummies, and year dummies. Robust standard errors clustered at the country level in parentheses; * $\mathrm{p}<0.1, * * \mathrm{p}<0.05, * * * \mathrm{p}<0.01$. 
ECA

(1) squared

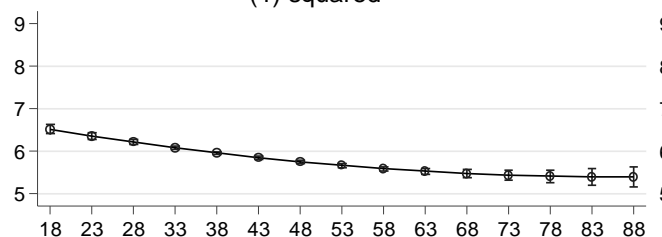

$\begin{array}{llllllllllllllll}18 & 23 & 28 & 33 & 38 & 43 & 48 & 53 & 58 & 63 & 68 & 73 & 78 & 83 & 88\end{array}$

(3) cubic

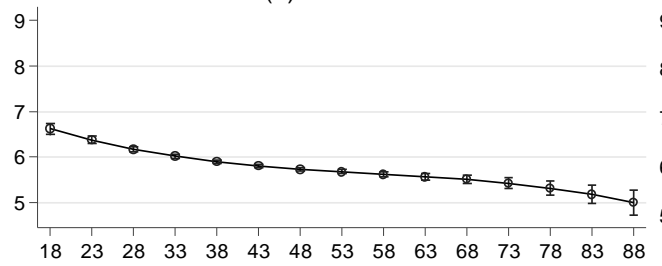

(5) non-parametric

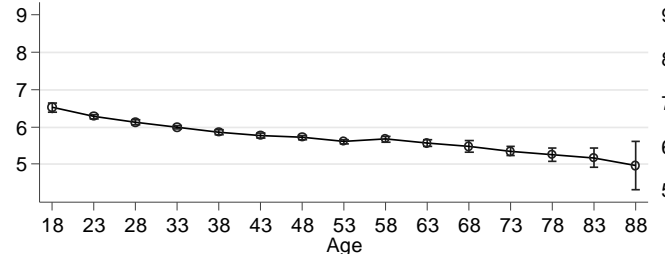

$\begin{array}{lllllllllllllll}18 & 23 & 28 & 33 & 38 & 43 & 48 & 53 & 58 & 63 & 68 & 73 & 78 & 83 & 88\end{array}$

Note: The panel numbers correspond to the regressions in Table A2
Western Europe

(2) squared

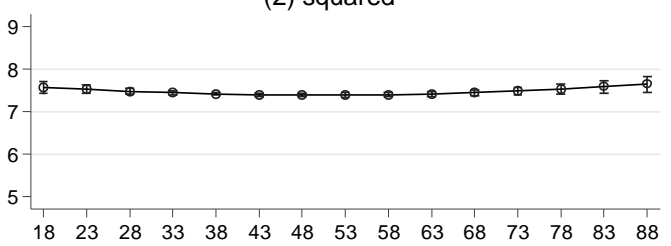

(4) cubic

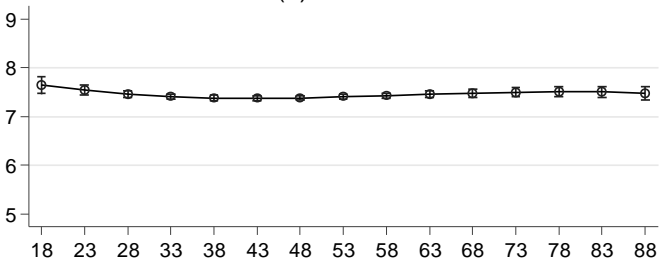

(6) non-parametric

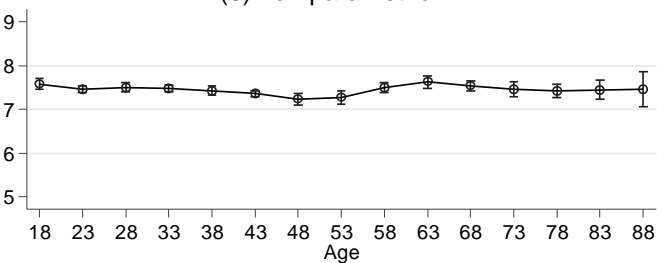

$\begin{array}{llllllll}53 & 58 & 63 & 68 & 73 & 78 & 83 & 88\end{array}$

Figure A1. Average marginal effects of subjective well-being over the lifespan: IVS data (1981-2009, without individual controls) 
Table A3 OLS estimates for ECA countries and Western Europe control with cohort dummies: IVS data (1981-2009, without individual controls)

\begin{tabular}{|c|c|c|c|c|c|c|}
\hline & $\begin{array}{c}(1) \\
\mathrm{ECA}\end{array}$ & $\begin{array}{c}\text { (2) } \\
\text { Western } \\
\text { Europe }\end{array}$ & $\begin{array}{c}(3) \\
\mathrm{ECA}\end{array}$ & $\begin{array}{c}(4) \\
\text { Western } \\
\text { Europe }\end{array}$ & $\begin{array}{c}(5) \\
\text { ECA }\end{array}$ & $\begin{array}{c}\text { (6) } \\
\text { Western } \\
\text { Europe }\end{array}$ \\
\hline Age & $\begin{array}{c}-0.01034 \\
(0.008)\end{array}$ & $\begin{array}{c}-0.01334 \\
(0.008)\end{array}$ & $\begin{array}{c}-0.09902^{* * * *} \\
(0.014)\end{array}$ & $\begin{array}{c}-0.04084^{* *} \\
(0.013)\end{array}$ & & \\
\hline Age squared & $\begin{array}{c}-0.00008 \\
(0.000)\end{array}$ & $\begin{array}{c}0.00016^{* *} \\
(0.000)\end{array}$ & $\begin{array}{c}0.00195^{* * *} \\
(0.000)\end{array}$ & $\begin{array}{c}0.00076^{* *} \\
(0.000)\end{array}$ & & \\
\hline Age cubic & & & $\begin{array}{c}-0.00001^{* * * *} \\
(0.000)\end{array}$ & $\begin{array}{c}-0.00000^{* *} \\
(0.000)\end{array}$ & & \\
\hline Age $23-27$ & & & & & $\begin{array}{c}-0.18920^{* * * *} \\
(0.048)\end{array}$ & $\begin{array}{c}-0.10343^{* * *} \\
(0.028)\end{array}$ \\
\hline Age $28-32$ & & & & & $\begin{array}{c}-0.25835^{* * *} \\
(0.049)\end{array}$ & $\begin{array}{c}-0.02814 \\
(0.067)\end{array}$ \\
\hline Age 33-37 & & & & & $\begin{array}{c}-0.31506^{* * *} \\
(0.060)\end{array}$ & $\begin{array}{c}-0.04544 \\
(0.068)\end{array}$ \\
\hline Age $38-42$ & & & & & $\begin{array}{c}-0.34959^{* * * *} \\
(0.091)\end{array}$ & $\begin{array}{c}-0.07060 \\
(0.081)\end{array}$ \\
\hline Age 43-47 & & & & & $\begin{array}{c}-0.39950^{* * * *} \\
(0.090)\end{array}$ & $\begin{array}{c}-0.13456 \\
(0.096)\end{array}$ \\
\hline Age 48-52 & & & & & $\begin{array}{c}-0.38530^{* * * *} \\
(0.097)\end{array}$ & $\begin{array}{c}-0.24997^{*} \\
(0.123)\end{array}$ \\
\hline Age 53-57 & & & & & $\begin{array}{c}-0.47819^{* * *} \\
(0.104)\end{array}$ & $\begin{array}{c}-0.20972 \\
(0.151)\end{array}$ \\
\hline Age 58-62 & & & & & $\begin{array}{c}-0.40513^{* * * *} \\
(0.120)\end{array}$ & $\begin{array}{c}0.01363 \\
(0.154)\end{array}$ \\
\hline Age 63-67 & & & & & $\begin{array}{c}-0.52836^{* * *} \\
(0.122)\end{array}$ & $\begin{array}{c}0.16624 \\
(0.152)\end{array}$ \\
\hline Age $68-72$ & & & & & $\begin{array}{c}-0.69023^{* * *} \\
(0.135)\end{array}$ & $\begin{array}{c}0.08562 \\
(0.153)\end{array}$ \\
\hline Age 73-77 & & & & & $\begin{array}{c}-0.84866^{* * *} \\
(0.148)\end{array}$ & $\begin{array}{c}0.03793 \\
(0.147)\end{array}$ \\
\hline Age $78-82$ & & & & & $\begin{array}{c}-1.05472^{* * *} \\
(0.138)\end{array}$ & $\begin{array}{c}0.03361 \\
(0.154)\end{array}$ \\
\hline Age $83-87$ & & & & & $\begin{array}{c}-1.18415^{* * *} \\
(0.194)\end{array}$ & $\begin{array}{c}0.06668 \\
(0.197)\end{array}$ \\
\hline Age $88-108$ & & & & & $\begin{array}{c}-1.45866^{* * *} \\
(0.342)\end{array}$ & $\begin{array}{c}0.14311 \\
(0.285)\end{array}$ \\
\hline Born 1920-29 & $\begin{array}{c}-0.11875 \\
(0.089)\end{array}$ & $\begin{array}{c}0.17101^{* *} \\
(0.072)\end{array}$ & $\begin{array}{c}-0.28706^{* * * *} \\
(0.091)\end{array}$ & $\begin{array}{c}0.15726^{*} \\
(0.069)\end{array}$ & $\begin{array}{c}-0.20254^{* *} \\
(0.092)\end{array}$ & $\begin{array}{c}0.13544 \\
(0.078)\end{array}$ \\
\hline Born 1930-39 & $\begin{array}{c}-0.29260^{* *} \\
(0.130)\end{array}$ & $\begin{array}{c}0.21639^{* *} \\
(0.072)\end{array}$ & $\begin{array}{c}-0.51200^{* * * *} \\
(0.136)\end{array}$ & $\begin{array}{c}0.20045^{* *} \\
(0.072)\end{array}$ & $\begin{array}{c}-0.40705^{* * *} \\
(0.129)\end{array}$ & $\begin{array}{c}0.19765^{*} \\
(0.095)\end{array}$ \\
\hline Born 1940-49 & $\begin{array}{c}-0.38779^{* *} \\
(0.169)\end{array}$ & $\begin{array}{c}0.16930 \\
(0.101)\end{array}$ & $\begin{array}{c}-0.57964^{* * * *} \\
(0.168)\end{array}$ & $\begin{array}{c}0.16767 \\
(0.102)\end{array}$ & $\begin{array}{c}-0.44160^{* * * *} \\
(0.156)\end{array}$ & $\begin{array}{c}0.16284 \\
(0.124)\end{array}$ \\
\hline Born 1950-59 & $\begin{array}{c}-0.44367^{* *} \\
(0.195)\end{array}$ & $\begin{array}{c}0.11573 \\
(0.130)\end{array}$ & $\begin{array}{c}-0.55835^{* * *} \\
(0.192)\end{array}$ & $\begin{array}{c}0.13385 \\
(0.132)\end{array}$ & $\begin{array}{c}-0.37232^{* *} \\
(0.171)\end{array}$ & $\begin{array}{c}0.15091 \\
(0.142)\end{array}$ \\
\hline Born 1960-69 & $\begin{array}{c}-0.36592^{*} \\
(0.202)\end{array}$ & $\begin{array}{c}0.22960 \\
(0.143)\end{array}$ & $\begin{array}{c}-0.42947^{* *} \\
(0.200)\end{array}$ & $\begin{array}{c}0.25470 \\
(0.145)\end{array}$ & $\begin{array}{c}-0.20905 \\
(0.181)\end{array}$ & $\begin{array}{c}0.21808 \\
(0.154)\end{array}$ \\
\hline Born 1970-79 & $\begin{array}{c}-0.19355 \\
(0.211)\end{array}$ & $\begin{array}{c}0.26216 \\
(0.154)\end{array}$ & $\begin{array}{c}-0.27485 \\
(0.213)\end{array}$ & $\begin{array}{c}0.28537 \\
(0.157)\end{array}$ & $\begin{array}{c}-0.01235 \\
(0.204)\end{array}$ & $\begin{array}{c}0.24058 \\
(0.154)\end{array}$ \\
\hline Born 1980-89 & $\begin{array}{c}-0.12819 \\
(0.216)\end{array}$ & $\begin{array}{c}0.31275 \\
(0.236)\end{array}$ & $\begin{array}{c}-0.25573 \\
(0.223)\end{array}$ & $\begin{array}{c}0.31879 \\
(0.237)\end{array}$ & $\begin{array}{c}0.04607 \\
(0.212)\end{array}$ & $\begin{array}{c}0.31807 \\
(0.236)\end{array}$ \\
\hline Born 1990-99 & $\begin{array}{c}0.25898 \\
(0.238)\end{array}$ & $\begin{array}{c}0.30558 \\
(0.240)\end{array}$ & $\begin{array}{c}0.03829 \\
(0.246)\end{array}$ & $\begin{array}{c}0.28233 \\
(0.231)\end{array}$ & $\begin{array}{c}0.40713^{*} \\
(0.222)\end{array}$ & $\begin{array}{c}0.29404 \\
(0.193)\end{array}$ \\
\hline Minimum & N/A & 43.0 & N/A & 38.6 & & \\
\hline Maximum & & & N/A & 88.6 & & \\
\hline $\begin{array}{l}N \\
\text { Adj. } R^{2}\end{array}$ & $\begin{array}{c}128690 \\
0.130\end{array}$ & $\begin{array}{c}44432 \\
0.058\end{array}$ & $\begin{array}{c}128690 \\
0.131\end{array}$ & $\begin{array}{c}44432 \\
0.059\end{array}$ & $\begin{array}{c}128690 \\
0.131\end{array}$ & $\begin{array}{c}44432 \\
0.060\end{array}$ \\
\hline
\end{tabular}

Note: The dependent variable is self-rated individual life satisfaction (10-point scale). Age ranges from 18 to 108, with age 18-22 as the reference in (5) and (6). For the cohort dummies, the reference group is those born between 1881 and 1919. The controls are country dummies, and year dummies. Robust standard errors clustered at the country level in parentheses; ${ }^{*} p<0.1,{ }^{* *} p<0.05,{ }^{* * *} p<0.01$ 

Table A4 OLS estimates of ECA countries including cohort effects, LiTS (2006-2010)

\begin{tabular}{|c|c|c|c|c|c|c|}
\hline & $(1)$ & $(2)$ & (3) & (4) & (5) & (6) \\
\hline Age & $\begin{array}{c}-0.0325^{* * * *} \\
(0.003)\end{array}$ & $\begin{array}{c}-0.0324^{* * * *} \\
(0.006)\end{array}$ & $\begin{array}{c}-0.0764^{\text {**** }} \\
(0.008)\end{array}$ & $\begin{array}{c}-0.0719^{* * * *} \\
(0.014)\end{array}$ & & \\
\hline Age squared & $\begin{array}{c}0.0004^{* * * *} \\
(0.000)\end{array}$ & $\begin{array}{c}0.0004^{* * * *} \\
(0.000)\end{array}$ & $\begin{array}{c}0.0013^{* * * *} \\
(0.000)\end{array}$ & $\begin{array}{c}0.0013^{* * *} \\
(0.000)\end{array}$ & & \\
\hline Age cubic & & & $\begin{array}{c}-0.00001^{* * * *} \\
(0.000)\end{array}$ & $\begin{array}{c}-0.00001^{* * * *} \\
(0.000)\end{array}$ & & \\
\hline Age $23-27$ & & & & & $\begin{array}{c}-0.1518^{* * * *} \\
(0.029)\end{array}$ & $\begin{array}{c}-0.1342^{* * *} \\
(0.029)\end{array}$ \\
\hline Age $28-32$ & & & & & $\begin{array}{c}-0.2067^{* * * *} \\
(0.032)\end{array}$ & $\begin{array}{c}-0.1478^{* * * *} \\
(0.040)\end{array}$ \\
\hline Age $33-37$ & & & & & $\begin{array}{c}-0.2829^{* * * *} \\
(0.032)\end{array}$ & $\begin{array}{c}-0.1969^{* * * *} \\
(0.044)\end{array}$ \\
\hline Age $38-42$ & & & & & $\begin{array}{c}-0.3078^{* * * * *} \\
(0.033)\end{array}$ & $\begin{array}{c}-0.2165^{* * * *} \\
(0.049)\end{array}$ \\
\hline Age $43-47$ & & & & & $\begin{array}{c}-0.3097^{\text {***** }} \\
(0.034)\end{array}$ & $\begin{array}{c}-0.2142^{* * * *} \\
(0.055)\end{array}$ \\
\hline Age $48-52$ & & & & & $\begin{array}{c}-0.2567^{* * * * *} \\
(0.038)\end{array}$ & $\begin{array}{c}-0.1534^{* * *} \\
(0.067)\end{array}$ \\
\hline Age $53-57$ & & & & & $\begin{array}{c}-0.2421^{\text {***** }} \\
(0.035)\end{array}$ & $\begin{array}{c}-0.1331^{*} \\
(0.067)\end{array}$ \\
\hline Age $58-62$ & & & & & $\begin{array}{c}-0.1579^{* * * *} \\
(0.035)\end{array}$ & $\begin{array}{r}-0.0421 \\
(0.069)\end{array}$ \\
\hline Age 63-67 & & & & & $\begin{array}{r}-0.0507 \\
(0.034)\end{array}$ & $\begin{array}{l}0.0719 \\
(0.071)\end{array}$ \\
\hline Age $68-72$ & & & & & $\begin{array}{l}-0.0207 \\
(0.042)\end{array}$ & $\begin{array}{l}0.1194^{*} \\
(0.068)\end{array}$ \\
\hline Age $73-77$ & & & & & $\begin{array}{l}0.0485 \\
(0.042)\end{array}$ & $\begin{array}{c}0.1962^{* * * *} \\
(0.070)\end{array}$ \\
\hline Age $78-82$ & & & & & $\begin{array}{c}0.1508^{* * * *} \\
(0.039)\end{array}$ & $\begin{array}{c}0.2862^{* * * *} \\
(0.065)\end{array}$ \\
\hline Age $83-87$ & & & & & $\begin{array}{c}0.2107^{* * * *} \\
(0.052)\end{array}$ & $\begin{array}{c}0.3374^{* * * *} \\
(0.092)\end{array}$ \\
\hline Age 88-99 & & & & & $\begin{array}{c}0.2035^{* * * *} \\
(0.062)\end{array}$ & $\begin{array}{c}0.3055^{* * *} \\
(0.116)\end{array}$ \\
\hline Born 1920-29 & & $\begin{array}{c}0.2106^{* *} \\
(0.101)\end{array}$ & & $\begin{array}{l}0.0437 \\
(0.119)\end{array}$ & & $\begin{array}{r}-0.0412 \\
(0.130)\end{array}$ \\
\hline Born 1930-39 & & $\begin{array}{c}0.2690^{\text {*** }} \\
(0.111)\end{array}$ & & $\begin{array}{l}0.0274 \\
(0.138)\end{array}$ & & $\begin{array}{l}-0.0628 \\
(0.142)\end{array}$ \\
\hline Born 1940-49 & & $\begin{array}{c}0.3285^{\text {*** }} \\
(0.126)\end{array}$ & & $\begin{array}{l}0.0725 \\
(0.153)\end{array}$ & & $\begin{array}{r}-0.0327 \\
(0.144)\end{array}$ \\
\hline Born 1950-59 & & $\begin{array}{l}0.2922^{*} \\
(0.144)\end{array}$ & & $\begin{array}{l}0.0669 \\
(0.164)\end{array}$ & & $\begin{array}{l}-0.0208 \\
(0.143)\end{array}$ \\
\hline Born 1960-69 & & $\begin{array}{l}0.2665^{*} \\
(0.150)\end{array}$ & & $\begin{array}{l}0.0878 \\
(0.163)\end{array}$ & & $\begin{array}{l}-0.0075 \\
(0.149)\end{array}$ \\
\hline Born 1970-79 & & $\begin{array}{l}0.2615^{*} \\
(0.151)\end{array}$ & & $\begin{array}{l}0.1095 \\
(0.159)\end{array}$ & & $\begin{array}{l}0.0024 \\
(0.150)\end{array}$ \\
\hline Born 1980-89 & & $\begin{array}{l}0.3185^{*} \\
(0.157)\end{array}$ & & $\begin{array}{l}0.1415 \\
(0.170)\end{array}$ & & $\begin{array}{l}0.0763 \\
(0.154)\end{array}$ \\
\hline Born 1990-92 & & $\begin{array}{c}0.3652^{* * *} \\
(0.156)\end{array}$ & & $\begin{array}{l}0.1479 \\
(0.171) \\
\end{array}$ & & $\begin{array}{l}0.1133 \\
(0.162) \\
\end{array}$ \\
\hline $\begin{array}{l}\text { Minimum } \\
\text { Maximum }\end{array}$ & 44.7 & 43.8 & $\begin{array}{l}41.3 \\
98.9\end{array}$ & $\begin{array}{c}39.4 \\
100.3\end{array}$ & & \\
\hline$N$ & 57950 & 57950 & 57950 & 57950 & 57950 & 57950 \\
\hline Adj. $R^{2}$ & 0.171 & 0.172 & 0.172 & 0.172 & 0.172 & 0.172 \\
\hline
\end{tabular}

Note: The dependent variable is self-rated individual life satisfaction (5-point scale). Age ranges from 18 to 99, with age 18-22 as the reference in (5) and (6). For the cohort dummies, the reference group is those born between 1909 and 1919. The controls are gender, employment status (employed versus not employed as the reference), marital status (married, not married as the reference), education (medium level education and high level education, with low level education as the reference), expenditure quintiles, self-reported health (5-point scale), country dummies, and year dummies. Robust standard errors clustered at the country level in parentheses; $* \mathrm{p}<0.1, * * \mathrm{p}<0.05, * * * \mathrm{p}<0.01$. 

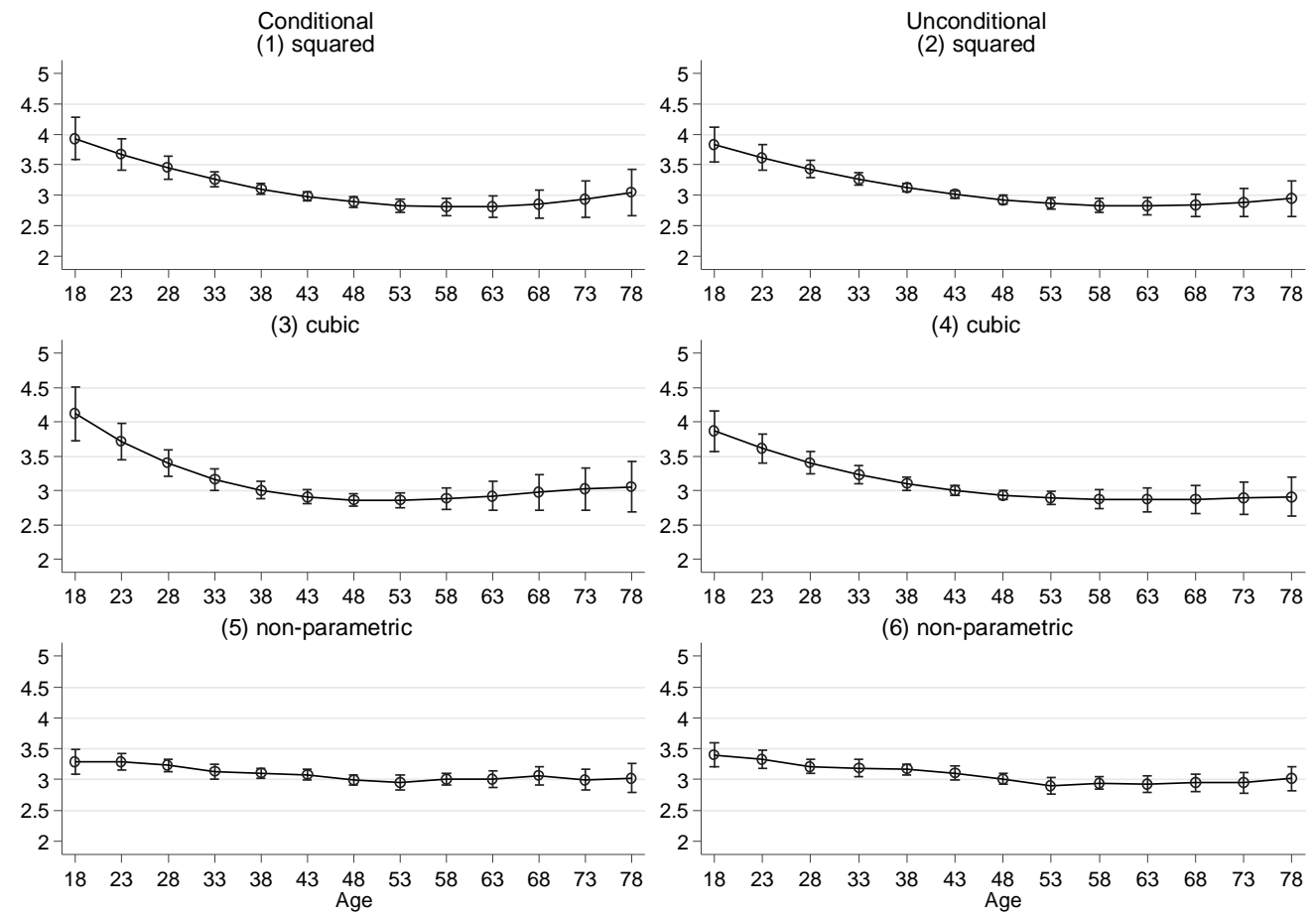

Figure A3 Average marginal effects of well-being over the lifespan in the synthetic panel regressions using

LiTS data (2006-2010) 
Table A5 Unconditional country-specific differences of life satisfaction in age minima and maxima: LiTS data (2006-2010)

\begin{tabular}{|c|c|c|c|}
\hline Country & Minimum & Maximum & Observations \\
\hline \multicolumn{4}{|c|}{ Countries with age minimum and maximum (S shape) } \\
\hline Azerbaijan & 42.1 & 63.6 & 1980 \\
\hline Hungary & 48.1 & 83.9 & 2039 \\
\hline Kyrgyz Republic & 36.2 & 57.6 & 1971 \\
\hline Latvia & 51.9 & 91.2 & 1996 \\
\hline Montenegro & 48.4 & 54.8 & 1951 \\
\hline \multicolumn{4}{|c|}{ Countries with age minimum ( $U$ shape) } \\
\hline Armenia & 59.4 & & 1913 \\
\hline Belarus & 57.5 & & 1887 \\
\hline Bulgaria & 88.1 & & 1988 \\
\hline Czech Republic & 69.4 & & 1981 \\
\hline Estonia & 55.9 & & 1987 \\
\hline FYR Macedonia & 54.0 & & 2014 \\
\hline Lithuania & 62.0 & & 1989 \\
\hline Moldova & 63.8 & & 1961 \\
\hline Poland & 86.7 & & 2586 \\
\hline Romania & 66.4 & & 2037 \\
\hline Russian Federation & 73.4 & & 2508 \\
\hline Serbia & 56.8 & & 2483 \\
\hline Slovenia & 60.9 & & 1963 \\
\hline Ukraine & 68.8 & & 2499 \\
\hline Uzbekistan & 55.8 & & 2452 \\
\hline \multicolumn{4}{|c|}{ Countries without age minimum or maximum } \\
\hline Albania & - & & 2030 \\
\hline Bosnia and Herzegovina & - & & 2061 \\
\hline Croatia & - & & 1962 \\
\hline Georgia & - & & 1979 \\
\hline Kazakhstan & - & & 1957 \\
\hline Slovak Republic & - & & 1986 \\
\hline Tajikistan & - & & 1946 \\
\hline Turkey & - & & 1972 \\
\hline
\end{tabular}




\section{Appendix 2: Description of variables}

\section{European Value Study and World Value Survey (IVS)}

Life satisfaction: The IVS assesses individual life satisfaction as follows: All things considered, how satisfied are you with your life as a whole these days? Responses are measured on a scale from 1 (dissatisfied) to 10 (satisfied).

Employment: It classifies individual employment status into five types: non-employed (reference group), full-time employed, part-time employed, self-employed and other, which includes retired, housewife, student, and those who selected other in the survey.

Marital status: The survey categorizes marital status into three states: single/never married (reference category), married/living together as married, and divorced/separated/widowed.

Health: In our analysis, we evaluate health based on self-reported health status, a subjective health indicator assessed by the following: All in all, how would you describe your state of health these days? Responses are measured on a 5-point scale: $1=$ very poor, $2=$ poor, $3=$ fair, $4=\operatorname{good}$ and $5=$ very good

Income: The IVS data contain income deciles based on survey year and country. We reduce these to quintiles to facilitate income comparisons.

Education: For manageability, we reduce the original IVS education levels to only three states: Low (omitted reference), containing inadequately completed elementary education, completed (compulsory) elementary education, incomplete secondary school: technical/vocational typel (compulsory) elementary education, and basic vocational qualification incomplete secondary: university-preparatory type/secondary, intermediate general qualification; Medium, consisting of complete secondary school: technical/vocational type/secondary, intermediate vocational qualification and complete secondary: university-preparatory type/full secondary, maturity level certificate; and 
High, covering some university without degree/higher education lower-level tertiary certificate and university with degree/higher education - upper-level tertiary certificate.

\section{The Life in Transition Survey}

Life satisfaction: In the LiTS, individual life satisfaction is based on the following question: $T o$ what extent do you agree with the following statements? All things considered, I am satisfied with my life now, with answers assessed on a scale from $1=$ strongly disagree to $5=$ strongly agree.

Household satisfaction: The wording of the item on household life satisfaction differs slightly in the 2006 and 2010 LiTS waves: My household lives better nowadays than around 1989 and my household lives better nowadays than around 4 years ago, respectively. Responses to both are assessed on a 5 -point scale from $1=$ strongly disagree to $5=$ strongly agree.

Employment status: Because precise data are unavailable, employment status is a binary variable that equals 1 if the respondent is currently employed and 0 otherwise.

Marital status: Marital status is rescaled as a binary variable ( $1=$-married, $0=$ not married).

Health: As before, we assess self-reported health status using a subjective health measure based on the following question: How would you assess your health? evaluated on a 5-point scale from $1=$ very bad to $5=$ very good. This variable is very close to the IVS, in which only wording and category names differ slightly.

Income: Because none of the income measures are sufficient for an international comparison, we proxy household expenses with spending, which differs slightly between the two waves. In 2006, spending included food, beverages, and tobacco, clothing and footwear, transport and communication (fixed-line phone, mobile phone, Internet) expenses, and recreation, entertainment, meals outside the home, etc. In 2010, it covered food, beverages and tobacco, utilities (electricity, water, gas, heating, fixed line phone) and transportation (public 
transportation, fuel for car). Based on these expenses, we calculate country-specific expense quintiles for every survey year.

Education: We reduce the original six LiTS education levels to only three: low, medium and high, constructed as follows: For 2006, low includes no degreeleducation and compulsory school education; medium comprises secondary education and professional, vocational school/training, and high consists of higher professional degree (university, college) and postgraduate degree. For 2010, the medium category contains three different classifications: lower secondary, (upper) secondary and post-secondary non tertiary. Both the other categories are constructed as in 2006 .

\section{Russia Longitudinal Monitoring Survey}

Life satisfaction: The RLMS evaluates individual life satisfaction as follows: To what extent are you satisfied with your life in general at the present time?, evaluated on a 5-point scale from $1=$ not at all satisfied to $5=$ fully satisfied.

Employment: Using the RLMS data, the individual employment status is a binary measure equal to 1 if the respondent is currently employed, 0 otherwise. The reference group is nonemployed.

Marital status: We recode the 5-point scale for marital status $(1=$ never married, $2=$ married, 3 $=$ married but not living together, $4=$ divorced and $5=$ separated/ widowed) as a 3 -point scale: $1=$ never married, $2=$ married $/$ married but not living together and $3=$ divorced/separated/widowed, with never married as the reference group. It should be noted, however, that no marital status information is available for Round V.

Health: Self-rated health status is measured by the question, Tell me, please, how would you evaluate your health status?, assessed on a 5-point scale: 1 = very bad, $2=$ bad, $3=$ average, $4=$ good and $5=$ very good. 
Income: To enable comparison with other data sets, we recode nominal household income into household income quintiles.

Education: We recode education levels on a 7-point scale: $0=$ no education, $1=$ obtaining $a$ diploma of professional course (e.g. typing or accounting courses), 2 = obtaining a PTU, FZU or FZO diploma without a secondary education, 3 = obtaining a PTU diploma with a secondary education, 4 = obtaining a technical education diploma, including medical, music, pedagogical and art school, $5=$ obtaining a university degree and $6=$ obtaining $a$ graduate degree and/or residency. The reference category is further education. 